\title{
Continental drift, plateau uplift, and the evolutions of monsoon and arid regions in Asia, Africa, and Australia during the Cenozoic
}

Article

Accepted Version

Liu, X., Dong, B., Yin, Z., Smith, R. and Guo, Q. (2019)

Continental drift, plateau uplift, and the evolutions of monsoon and arid regions in Asia, Africa, and Australia during the Cenozoic. Science China Earth Sciences, 62 (7). pp. 10531075. ISSN 1869-1897 doi: https://doi.org/10.1007/s11430018-9337-8 Available at https://centaur.reading.ac.uk/83019/

It is advisable to refer to the publisher's version if you intend to cite from the work. See Guidance on citing.

To link to this article DOI: http://dx.doi.org/10.1007/s11430-018-9337-8

Publisher: Science China

All outputs in CentAUR are protected by Intellectual Property Rights law, including copyright law. Copyright and IPR is retained by the creators or other copyright holders. Terms and conditions for use of this material are defined in the End User Agreement. 


\section{CentAUR}

Central Archive at the University of Reading

Reading's research outputs online 


\title{
Continental drift, plateau uplift, and the evolutions of monsoon and arid
}

\author{
regions in Asia, Africa, and Australia during the Cenozoic
}

\author{
Xiaodong LIU ${ }^{1,2,3 *}$, Buwen DONG ${ }^{4}$, Zhi-Yong YIN ${ }^{5}$, Robin S. SMITH ${ }^{4}$ \& Qingchun GUO \\ ${ }^{1}$ State Key Laboratory of Loess and Quaternary Geology, Institute of Earth Environment, Chinese \\ Academy of Sciences, Xi' an 710075, China; \\ ${ }^{2}$ College of Earth and Planetary Sciences, University of Chinese Academy of Sciences, Beijing \\ 100049, China; \\ ${ }^{3}$ CAS Center for Excellence in Tibetan Plateau Earth Sciences, Beijing 100101, China; \\ ${ }^{4}$ National Centre for Atmospheric Science, University of Reading, Reading, RG6 6BB, UK; \\ ${ }^{5}$ Department of Environmental \& Ocean Sciences, University of San Diego, San Diego, 92110, \\ USA; \\ ${ }^{6}$ School of Environment and Planning, Liaocheng University, Liaocheng 252000, China \\ ${ }^{*}$ Corresponding author (email: liuxd@loess.llqg.ac.cn)
}

\begin{abstract}
Monsoon and arid regions in the Asia-Africa-Australia (A-A-A) realm occupy more than $60 \%$ of the total area of these continents. Geological evidence showed that significant changes occurred to the A-A-A environments of the monsoon and arid regions, the land-ocean configuration in the Eastern Hemisphere, and the topography of the Tibetan Plateau in the Cenozoic. Motivated by this background, numerical experiments for 5 typical geological periods during the Cenozoic were conducted using a coupled ocean-atmosphere general circulation model to systemically explore the formations and evolutionary histories of the Cenozoic A-A-A monsoon and arid regions under the influences of continental drift and plateau uplift. Results of the numerical experiments indicate that the timings and causes of the formations of monsoon and arid regions in the A-A-A realm were very different. The northern and southern African monsoons existed during the midPaleocene, while the South Asian monsoon appeared in the Eocene after the Indian Subcontinent moved into the tropical Northern Hemisphere. In contrast, the East Asian monsoon and northern Australian monsoon were established much later in the Miocene. The establishment of the tropical monsoons in northern and southern Africa, South Asia, and Australia were determined by both the continental drift and seasonal migration of the Inter-Tropical Convergence Zone (ITCZ), while the position and height of the Tibetan Plateau were the key factor for the establishment of the East Asian monsoon. The presence of the subtropical arid regions in northern and southern Africa, Asia, and Australia depended on the positions of the continents and the control of the planetary scale subtropical high pressure zones, while the arid regions in the Arabian Peninsula and West Asia were closely related to the retreat of the Paratethys Sea. The formation of the mid-latitude arid region in the Asian interior, on the other hand, was the consequence of the uplift of the Tibetan Plateau. These results from this study provide insight to the important roles played by the earth's tectonic boundary conditions in the formations and evolutions of regional climates during geological times.
\end{abstract}

Keywords Cenozoic, monsoon region, arid region, continental drift, Tibetan Plateau uplift, climate simulation 


\section{Introduction}

Monsoon and arid climates are two climate types commonly seen in mid- and low-latitudes of the Earth. These climate types have sculpted the corresponding ecosystems, landforms, and the living environments of human society. The most well-known monsoon regions are found in tropical Africa, South and East Asia, and Australia, while northern Africa, interior of Asia, and central Australia contain the largest tracts of arid land. However, during the geological history of Earth, the distributions of monsoon and arid climates changed over time, and in places like East Asia, and southern and northern Africa, areas of either monsoon or arid climates evolved at different times. The origins of these climates, the physical mechanisms associated with their formations, the timing and controlling factors of their appearances, and the evolutionary histories of these climates have been the subjects of research for the scientific community but there is currently no consensus on these questions yet.

According to the geological evidence, monsoon climates appeared in different regions at different times. In South Asia, a switch from forest vegetation to grassland in northern Pakistan (Qaude et al., 1989) and increased upwelling off the coast of the Arabian Sea (Kroon et al., 1991) have been considered as the major evidence of the appearance of the South Asian monsoon in the late-Miocene (7-8 Ma). Later studies based on proxies of a monsoon climate from the Arabian Sea suggested that the South Asian monsoon system first appeared in the mid-Miocene (12 Ma), but was not fully established until the late-Miocene (Gupta et al., 2015; Zhuang et al., 2017). Other studies, however, suggested that the South Asian monsoon may have existed as early as the Eocene. For example, Shukla et al. (2014) proposed that the South Asian monsoon existed in the early-Eocene based on lacustrine deposits from Rajasthan in North India. Spicer et al. (2017) concluded that the imprints of a monsoon climate could be seen in the records of plant fossils and estimated seasonality of precipitation in India and its surroundings. They speculated that a monsoon climate first appeared around $56 \mathrm{Ma}$ in South Asia and the most southern part of China. In East Asia, it was originally proposed that monsoon climate first appeared in the early-Quaternary (2.6 Ma), based on the paleosol-loess sequence that reflected the alternation between periods of dominant winter and summer monsoons (Liu, 1985; Ding et al., 1992; An 2000). Later, the history of the East Asian monsoon was extended to the late-Miocene $(8 \mathrm{Ma}$ ) based on the studies on the eolian red clay deposits beneath the loess (An, 2000; An et al., 2001). The discovery of the loess during the earlyMiocene (Guo et al., 2000) and the changes in the vegetation zonation in China during the Cenozoic (Sun and Wang, 2005) pushed the timing of monsoon formation back to the end of the Oligocene to the beginning of the Miocene ( 22 Ma). Also based on plant fossils, Quan et al. (2012) suggested that a monsoon climate had already dominated large areas in East China as early as the Eocene, but this opinion is still questioned by others (e.g., Liu et al., 2017). Due to limited geological evidence, the records of African and Australian monsoons are relatively short at this point. For example, Linder (2017) described the Eocene climate in East Africa as a forest climate with strong seasonality based on a small quantity of fossil records, while a more affirmative date for the African monsoon could only be traced back to the late-Miocene (De Menocal, 1995; Colin et al., 2014). In the meantime, geological evidence for the northern Australian monsoon only went back to the lateQuaternary (Bowler et al., 2001; Wyrwoll and Miller 2001). Because of the lack of well-preserved paleoclimate proxies and/or relatively few attempts of research so far, these limited records of paleomonsoons provide insufficient evidence for a comprehensive discussion of the origins and evolutionary processes of monsoon climates in these regions. 
The study of the evolution of arid environments in Asia-Africa-Australia has made great strides since the late 1990s. Eolian deposits from the Loess Plateau of China and the North Pacific are good proxies of aridification of the Asian interior (Guo et al., 2002; Rea et al. 1998). There have been many geological records suggesting various degrees of aridification in the Asian interior during the Pliocene to late-Miocene (Sun and An 2002; Sun et al. 2015), Miocene (Caves et al., 2016), Oligocene-Miocene transition (Sun and Windley, 2015), and the Eocene (Bosboom et al., 2014; Fang et al., 2015; Li et al., 2018a). However, the best way to describe the changes in the East Asia arid region is through using various biogeological evidences to reconstruct the spatial patterns of paleoenvironments during different geological periods, rather than being restrained to individual records at specific locations. An atlas of paleoenvironments reconstructed using plant fossils and sedimentary deposits in China showed a broad arid zone running from west to east across mainland China during the Paleogene (Guo et al., 2008), while in the Neogene, the arid zone was limited to Northwest China. Therefore, it has been proposed that during the Oligocene-Miocene transition, the East Asia atmospheric circulation experienced changes from a regime mainly controlled by the planetary winds to a monsoon-dominated regime (Sun and Wang, 2005; Guo et al. 2008). In contrast, the geological records representing the evolutionary history of the arid regions in Africa and Australia are relatively rare at this point. There is evidence indicating wetter conditions for most of Africa during the early Cenozoic and that significant aridification occurred after the Miocene, especially since the Pliocene (Bobe, 2006; Kakhki et al., 2016). Senut et al. (2009) suggested that the main period of aridification in Africa was during the Neogene. For example, Veranso-Libalah et al. (2018) speculated that aridification intensified during the Neogene, as indicated by multiple shifts of the habitats of Melastomateae plants in Sub-Sahara Africa. In the late-Miocene, the Sahara Desert and other deserts in the Middle East and Arabian Peninsula significantly expanded (Zhang et al., 2014). In the meantime, aridification in Australia intensified in the early-Miocene, while the midMiocene and early-Pliocene were important periods for the development of arid regions there (Fjioka and Chappell, 2010; Martin, 2006; Williams, 2015; Rix et al., 2017). Additionally, the differentiation between the subtropical arid region and tropical monsoon occurred in the midMiocene in Australia (Marin et al., 2013).

Numerous climatological studies, especially climatic modeling studies, have been conducted to examine the formation mechanisms of monsoon and arid climates from different perspectives. The most prominent continental drift and plateau uplift due to plate movements occurred in the Eastern Hemisphere after the beginning of the Cenozoic (Scotese, 2004). For example, the IndoAustralian Plate (Molnar and Stock, 2009; Hall, 2002) moved rapidly toward north and the resulting collision caused large-scale tectonic uplift of the mountains in the mid- to low-latitude regions of Asia, characterized by the Tibetan Plateau uplift (Wang et al., 2014). Therefore, many studies linked the origins of monsoon and arid climates with the changing land-sea configuration and the characteristics of topography. In terms of the formation of the monsoon climate, the traditional theory of climatology regards it as the result of seasonal alternation of the thermal contrast between land and ocean (Webster, 1987). More specifically for Asia, the Cenozoic uplift of the Tibetan Plateau (Kutzbach et al., 1992; Liu and Yin, 2002) or the changes of land-ocean configuration associated with the retreat of the Paratethys Sea (Ramstein et al., 1997) could all have affected the land-ocean thermal contrast and thereby influenced the formation and evolution of the Asian monsoons. In contrast, the tropical monsoon is considered as the manifestation of the seasonal migration of the Inter-Tropical Convergence Zone (ITCZ) (Gadgil, 2003, 2018). On the one hand, 
connections between regional monsoons and the ITCZ allowed changes in regional monsoons to modulate the global monsoon (Wang and Ding, 2006). On the other hand, monsoon evolution on geological time scales is also closely related to the ITCZ (Wang, 2009). Additionally, modeling studies have suggested that the extremely high $\mathrm{CO}_{2}$ concentration during certain geological times may be a determining factor for the formation of monsoon climates. For example, the late-Eocene $\mathrm{CO}_{2}$ concentration was several times higher than today's level, which may have effectively intensified hydrological cycle and produced monsoon climates at that time (Licht et al., 2014). As regard to the causes of aridification during geological times, some geological evidence suggested that the aridification of the Asian interior was related to the retreat of the Paratethys Sea (Bosboom et al., 2014; Sun and Windley, 2015), uplift of the Tibetan Plateau (Rea et al., 1998; Dettman et al., 2003), and the global cooling during the Cenozoic (Lu and Guo, 2014; Fang et al., 2015; Li et al., 2018a). Numerical modeling studies, however, tended to emphasize the effects of the plateau uplift (Manabe and Broccoli, 1990; Kutzbach et al., 1993), especially the uplift of the northern Tibetan Plateau (Liu and Dong, 2013), as well as global cooling (Li et al., 2018a), and the feedback mechanisms associated with regional desertification (Liu et al., 2015b).

From the above discussion, it can be concluded that the origins, evolutionary histories and the formation mechanisms of the Cenozoic Asian-African-Australian monsoon and arid climates are still unclear. A recent study by us (Liu et al., 2017) considered the combined effects of continental drift, plateau uplift, and atmospheric $\mathrm{CO}_{2}$ concentration, and explored the origins and evolutions of the Asian and Australian monsoons using numerical simulations. In the current study, we expand the scope of that study to Africa and also include the origins and evolutions of arid regions in the Africa-Asia-Australia realm (A-A-A hereafter). In this way, we will further analyze the relationships of the origins and evolutionary processes of both monsoon and arid climates to continental drift and plateau uplift in this large realm, so that we can get a more complete understanding on the longterm climatic evolutionary processes in the mid- and low-latitude regions of the Eastern Hemisphere.

\section{Description of the numerical experiments and delineation of the present day monsoon and arid regions}

The climate model used in this study is the Fast Met Office and UK universities Simulator - a coupled Atmosphere Ocean General Circulation Model (FAMOUS AOGCM) (Jones et al., 2005; Smith et al., 2008). The spatial resolution of the atmospheric component of FAMOUS is $5^{\circ} \times 7.5^{\circ}$ with 11 vertical layers, while the spatial resolution of the ocean component is $2.5^{\circ} \times 3.75^{\circ}$, with 20 vertical levels. The atmosphere and ocean components are coupled once every day, with no adjustments to the fluxes. Because of the low spatial resolutions, the FAMOUS model runs quickly and is especially suitable for paleoclimatic simulations that require long running times. This model has been used widely with good simulations of both present day and future climate, such as those in Smith and Gregory (2012) and Liu et al. (2015a).

This study presents three sets of numerical experiments. The first set contains 5 basic experiments using reconstructed land-ocean configurations (Gurnis et al., 2010) and topography (Liu et al., 2017) based on geological evidence to represent five geological periods during the Cenozoic: the mid-Paleocene (MP, $\sim 60 \mathrm{Ma}$ ), late-Eocene (LE, $\sim 40 \mathrm{Ma}$ ), late-Oligocene (LO, $\sim 25$ $\mathrm{Ma}$ ), late-Miocene ( $\mathrm{LM}, \sim 10 \mathrm{Ma}$ ), and the present-day (PD, $\sim 0 \mathrm{Ma}$ ). The land-ocean distributions during geological times were mainly based on data from the database of GPlates, an open-source software for reconstruction of plate motions during geological times (http://www.gplates.org/). For 
Asia and Europe, the coastlines were modified according to various regional geological evidences (e.g., Popov et al., 2006). Paleotopography and paleobathymetry were built based on previous reconstructions (Herold et al., 2008; Huber and Goldner, 2012), but revised using a large amount of published paleoelevation data (ref. Liu et al., 2017). The reconstructed topographic features included the Polar regions, Rocky Mountains, Andes Mountains, Tibetan Plateau and other mountains in its surroundings. Since the earliest uplift of the Tibetan Plateau probably occurred around 50-55 Ma (Searle et al., 1987), the elevation of the entire globe was set as $0 \mathrm{~m}$ for $60 \mathrm{Ma}$ to remove the effects of mountains and plateaus. The paleotopography of the Rocky Mountains was revised for $40 \mathrm{Ma}$ according to Fan and Carrapa (2014); Greenland topography was revised according to Zachos et al. (2001) for $25 \mathrm{Ma}$ and $10 \mathrm{Ma}$, and the Andes Mountains were revised for $10 \mathrm{Ma}$ according to Carrapa et al. (2014). The paleotopography of the Tibetan Plateau was reconstructed from 40 Ma to 10 Ma using paleoelevation data from various sources (Wang et al., 2014; Ding et al., 2014; Rowley and Currie, 2006; DeCelles et al., 2007; Polissar et al., 2009). Changes in paleolatitude were also considered for the Tibetan Plateau (Besse et al., 1984; Chatterjee et al., 2013; Wei et al., 2013). Based on the records of the Cenozoic atmospheric $\mathrm{CO}_{2}$ concentrations (Beerling and Royer, 2011), the LE experiment used $\mathrm{CO}_{2}$ concentration 4 times of the pre-industrial level of 280 ppmv, all other 4 experiments adopted the pre-industrial $\mathrm{CO}_{2}$ level for their respective geological periods. For the sake of simplicity, all vegetation and soil properties were set uniformly for the entire globe. In other words, except for Antarctica, all land grids were given the average nonice condition of the pre-industrial age. Additionally, since this study mainly examines the average climatic conditions at the million-year time scale, the effects of orbital forcing can be ignored, so that all orbital parameters were set at present day values.

The second set contains four comparative experiments without topography, matched to the 4 experiments in the first set for LE, LO, LM, and PD. These comparative experiments have the same land-ocean configurations as their counterparts in the first set, but with all elevations being set to 0 $\mathrm{m}$. By comparing the simulation results between these two sets of experiments the effects of topography can be revealed. The third set contains two comparative experiments of the reduced $\mathrm{CO}_{2}$ concentration for the late-Eocene. Using the same land-ocean configuration of LE experiment in the first set, the pre-industrial $\mathrm{CO}_{2}$ level was applied to the experiments with and without topography. By comparing these results with the $4 \mathrm{x} \mathrm{CO}_{2}$ experiments in first and second sets, we can analyze the effects of $\mathrm{CO}_{2}$ concentration under the scenarios with and without global topography. More details on the experimentation design and the boundary conditions related to the land-ocean configuration and plateau topography can be found in Liu et al. (2017) and the online supplementary information (https://media.nature.com/original/nature-assets/srep/2017/170113/ srep40344/extref/srep40344-s1.pdf). All experiments were run for 1000 years and all analyses below are based on the averages of the last 100 years for each experiment.

In order to objectively portray the locations and evolutionary histories of the monsoon and arid regions, it is necessary to quantitatively define these climate regions first. Since the precipitation regimes of monsoon climates are mostly characterized by alternating dry and rainy seasons, we used precipitation seasonality to determine monsoon regions as suggested by Wang and Ding (2006). Hence, a monsoon region is defined as where the difference between summer and winter precipitation is greater than $200 \mathrm{~mm}$ and summer rainfall exceeds $40 \%$ of the annual total. Summer is the rainy season, as June-July-August (JJA) for the Northern Hemisphere (NH) and DecemberJanuary-February (DJF) for the Southern Hemisphere (SH), while winter is the dry season as DJF 
in $\mathrm{NH}$ and JJA in SH. Considering the possibility that the East Asian monsoon may expand to the mid-latitude region, we added another constraint for the $\mathrm{NH}$ monsoons by defining the northern boundary of the summer monsoon as the most northward position for the southerly winds from the tropical oceans on the $850 \mathrm{hPa}$ level. In climatology and physical geography, regions with annual rainfall lower than $200 \mathrm{~mm}(200-400 \mathrm{~mm}$ ) are commonly defined as arid (semi-arid) regions (Zhao, 1983; Liu et al. 2015a). In this study, we collectively defined arid regions as those with annual rainfall lower than $400 \mathrm{~mm}$.

Based on the above definitions, we first examined the distributions of the monsoon and arid regions in the PD experiment (Figure 1a) and compared it with the observation-based CMAP precipitation data (Xie and Arkin, 1996) (Figure 1b). The comparison shows that the simulation results replicate the modern distributions of the monsoon and arid regions in the A-A-A realm very well. The simulated monsoon regions include the northern and southern African topical monsoon regions, a belt of monsoon climates from South Asia to Korea Peninsula in East Asia, and the northern Australian monsoon (Figure 1a), matching the observed distribution pattern well (Figure 1b). Except for East Asia where monsoon climate extended to $40^{\circ} \mathrm{N}$, all other simulated monsoon regions are limited between the latitudes of $25^{\circ} \mathrm{N}$ and $25^{\circ} \mathrm{S}$, belonging to the tropical monsoon climate. However, when compared with the observed distribution pattern, the simulated northern boundary of the northern African monsoon is slightly further north than the observed, while the southern boundary of the Australian monsoon is further south, making these two monsoon regions larger than the observed. In the meantime, the simulated monsoon region over eastern Tibetan Plateau is also larger than observed, while the monsoon region in Northeast China is slightly smaller. The simulated arid regions also match the observed distribution pattern well, from northern Arica to the Arabian Peninsula, West and Central Asia, and to the vast arid region in the interior of East Asia. Except for arid regions in Central Asia and the interior of East Asia located in the mid-latitude regions, all other arid regions are found in the $\mathrm{NH}$ and $\mathrm{SH}$ subtropical regions. When compared with the observed distribution pattern in Figure 1b, it can be seen that because the simulated northern boundary of the northern African monsoon region is placed further north than the observed, the corresponding southern boundary of the northern African arid region is also pushed to the north, causing their size to be underestimated. Additionally, since the simulated summer rainfall over the Tibetan Plateau is greater than the observed amount, the arid climate region in the northern plateau is not accurately portrayed, which reduces the size of the simulated arid region in East Asia (Figure 1b). Nevertheless, FAMOUS, as a low-resolution climate model, is very successful in simulating the distribution pattern of the monsoon and arid regions in the A-A-A realm, which forms the foundation for us to conduct simulations on the evolutionary histories of the monsoon and arid regions during geological times.

\section{Spatio-temporal evolutions of the Cenozoic monsoon and arid regions in the A-A-A realm}

Since the beginning of the Cenozoic, significant environmental changes have occurred to the monsoon and arid regions of the A-A-A realm due to continental drift and uplift of the Tibetan Plateau. Based on the definitions of the monsoon and arid regions depicted in the previous section, we can determine the simulated spatial distributions and temporal evolutions of monsoon and arid regions across the A-A-A realm during the 5 geological periods of the Cenozoic (Figure 2). For the monsoon regions, the northern and southern African monsoon regions existed in the mid-Paleocene (Figure 2a). The size of the Asian continent was much smaller than in modern times and a monsoon 
climate only existed in Indochina south of $20^{\circ} \mathrm{N}$. As the Indian Subcontinent was still located in the SH tropical latitudes, it was influenced by the SH tropical monsoon climate. Therefore, the monsoon regions in the early Cenozoic in India and southern China as described in Spicer et al. (2017), determined by the distribution of tropical plants, were actually separated by the equator. In the lateEocene (Figure 2b), the northern African monsoon region did not change much, but the southern African monsoon significantly expanded southward. The Indian Subcontinent had moved into the $\mathrm{NH}$ and was connected with the Asian continent. At this time, monsoon climates appeared in northern and central India, Bay of Bengal, and southern Tibetan Plateau that had just begun to uplift, while southern India did not have a typical monsoon climate as it was located at the equator with high rainfall throughout the year. These results match well with existing Eocene simulation results (Huber and Goldner, 2012) in which the global tropical monsoon was established. In the lateOligocene (Figure 2c), monsoon regions in northern and southern Africa and South Asia had a similar distribution pattern as in the late-Eocene, except that monsoon climates covered the entire Indian Subcontinent and Indochina. In the late-Miocene (Figure 2d), the monsoon regions in northern and southern Africa and South Asia all stabilized, while East Asia underwent major changes, with a monsoon climate appearing in northern East Asia (north of $30^{\circ} \mathrm{N}$ ) and reaching North China to approximately $38^{\circ} \mathrm{N}$. Another major change occurred in Australia. With the continued northward movement, northern Australia moved into the SH tropical latitudes and was influenced by the SH tropical monsoon, including the region from Darwin to Cape York Peninsula, and further north to Papua New Guinea. Up to the present day (Figure 2e), no major changes occurred for the monsoon regions in Africa and South Asia, although the East Asian monsoon region expanded further northward beyond $40^{\circ} \mathrm{N}$. In the meantime, northern Australia moved to north of $20^{\circ} \mathrm{S}$ and the Australian monsoon region further increased significantly in size.

With regard to the temporal evolution of the arid regions, the arid regions in northern and southern Africa already existed in the mid-Paleocene (Figure 2a). However, since the African continent was positioned south of its present location, the arid region in northern Africa was much smaller than its counterpart in southern Africa, which is opposite to the present-day situation (Figure 2e). In Asia, the arid regions were mostly located between $22^{\circ} \mathrm{N}$ and $37^{\circ} \mathrm{N}$. In the late-Eocene (Figure 2b), the arid region in northern Africa did not experience much change, similar to the monsoon region there at this time, but the arid region in southern Africa became smaller as the African continent moved slightly to the north and the monsoon region in southern Africa expanded. In the meantime, the size of the Asian continent increased significantly as the Indian Subcontinent moved into the NH. As a result, the subtropical arid region north of the South Asian monsoon region enlarged significantly. The climate simulation by Zhang et al. (2012) also showed that the Asian arid zone was located between $20^{\circ} \mathrm{N}$ and $40^{\circ} \mathrm{N}$ during the Eocene. In the late-Oligocene (Figure 2c), as the African continent continued to move northward, the arid region in northern Africa expanded rapidly while the subtropical arid region in Asia expanded from West Asia all the way to the coast of East Asia. In the late-Miocene (Figure 2d), as the Tibetan Plateau continued to uplift and shifted northward, the arid region in the northwestern plateau disappeared. Consequently, the original contiguous arid zone was broken up into the western arid region from the Arabian Peninsula to West Asia and the mid-latitude East Asian arid region between the northern Tibetan Plateau and southern Mongolian Plateau. At the same time, as the Australian continent moved northward, a large arid region appeared in central and northern Australia. From the late-Miocene to the present day (Figure 2e), the arid region in northern Africa expanded further, but in Australia the arid region was reduced 
in size as the northern Australian monsoon region enlarged with the northward motion of the continent.

In order to quantify the relative changes of the monsoon and arid regions over time, we calculated the sizes of these regions over the different geological periods (Fig 3). During the entire Cenozoic, the monsoon regions in northern (Figure 3a) and southern (Figure 3b) Africa were relatively stable. The size of the northern African monsoon region mainly varied between $8,000,000-10,000,000 \mathrm{~km}^{2}$, while the size of the southern African monsoon region was about half of that varying around 4,000,000 $\mathrm{km}^{2}$. The size of monsoon regions in Asia increased significantly since the Miocene (Figure 3c), from approximately 4,000,000 $\mathrm{km}^{2}$ at $10 \mathrm{Ma}$ to $10,000,000 \mathrm{~km}^{2}$ at the present day. This was mainly achieved by the expansion of the East Asian monsoon region in the mid-latitudes (Figure $2 \mathrm{~d}$ and $2 \mathrm{e}$ ). A monsoon climate first appeared in the most northern part of Australia at $10 \mathrm{Ma}$ with an area of less than $200,000 \mathrm{~km}^{2}$ (Figure 3d), while its current area is over $3,000,000 \mathrm{~km}^{2}$. In contrast, the sizes of the arid regions in northern and southern Africa experienced significant changes. At $40 \mathrm{Ma}$ and earlier, the size of the northern African arid region was less than $1,000,000 \mathrm{~km}^{2}$ (Figure 3e), but its size increased to more than 4,000,000 $\mathrm{km}^{2}$ after $25 \mathrm{Ma}$. For the southern African arid region, its size was over $5,000,000 \mathrm{~km}^{2}$ at $60 \mathrm{Ma}$ (Figure 3f), but reduced to less than 2,000,000 $\mathrm{km}^{2}$ since $40 \mathrm{Ma}$. Because the current West and East Asian arid regions are separate, we calculated the size changes for the West Asian arid region (from the Arabian Peninsula to $70^{\circ} \mathrm{E}$ ) and the East Asian arid region (the interior Asia east of $70^{\circ} \mathrm{E}$ ) and, for ease of comparison, the latter includes the arid regions in both Central Asia and East Asia. During the mid-Paleocene, there was no arid region in West Asia. At $40 \mathrm{Ma}$, the size of arid region in West Asia increased to approximately $3,000,000 \mathrm{~km}^{2}$, which was doubled to about $6,000,000 \mathrm{~km}^{2}$ at $25 \mathrm{Ma}$ and then maintained at this level since (Figure $3 \mathrm{~g}$ ). The East Asian arid region gradually increased from approximately $2,000,000 \mathrm{~km}^{2}$ at $60 \mathrm{Ma}$ to $5,000,000 \mathrm{~km}^{2}$ at $25 \mathrm{Ma}$ (Figure $3 \mathrm{~h}$ ). Afterward, its area was reduced to below 2,000,000 $\mathrm{km}^{2}$ at $10 \mathrm{Ma}$, which was maintained till the present day. From the Oligocene to Miocene, the East Asian arid region shrank to the continental interior north of the Tibetan Plateau (Figure 2d), as a consequence of the appearance of the East Asian monsoon as well as enhanced precipitation caused by the uplift of the northwestern Tibetan Plateau (Liu et al., 2015b). The Australian arid region did not exist prior to the Oligocene (Figure 3i), but at 10 Ma there was a broad arid region with an area greater than $4,000,000 \mathrm{~km}^{2}$. Afterward, its area shrank by $2 / 3$ in the present day. From the above, it can be seen that the monsoon and arid regions in different continents have very different evolutionary histories during the Cenozoic.

\section{Controlling effects of atmospheric circulation on the evolutions of the A-A-A monsoon and arid regions}

4.1. Distribution of monsoon regions and the seasonal migration of the ITCZ

Distributions of monsoon and arid regions are closely related to atmospheric circulation patterns. Modern climatology has revealed that the tropical monsoon is the manifestation of the seasonal migration of the ITCZ (Gadgil, 2018). In order to examine the evolution of the ITCZ during the Cenozoic and its relationship with the distribution of monsoon regions in different geological periods, we need to first quantify the position of the ITCZ. Traditionally, the ITCZ is defined as the convergence zone of the $\mathrm{NH}$ and $\mathrm{SH}$ trade winds and expressed as a planetary scale low pressure zone with high precipitation. However, several studies discovered that the convergence of the trade winds might not always match with the belt of high convective rainfall (Nicholson, 2009). 
Especially over the land masses, the meridional zero-wind contour and the convergence line were not suitable for defining the position of the ITCZ (Žagar et al., 2011). Therefore, other methods have been designed to determine the ITCZ, such as using the mean divergence field in the lower stratosphere (Berry and Reeder, 2014) or the field of specific humidity (Läderach and Raible, 2013) to represent the position of the ITCZ. Considering the strong correlations between rainfall, vertical motion, and convective activity in the equatorial regions, we used the mid-troposphere $500 \mathrm{hPa}$ vertical velocity $(\omega)$ to determine the position of the ITCZ. Figure 4 shows the average DJF and JJA $\omega$ and the corresponding distribution of precipitation during different geological periods. It can be seen that areas of strong upward motion (negative $\omega$ values) matched perfectly with regions with high rainfall, which also displayed systemic seasonality. At a particular geological period, the regions with upward motion and high precipitation during DJF (JJA) were preferably located in the $\mathrm{SH}(\mathrm{NH})$. For the entire Cenozoic, the ITCZ defined in this way only showed relatively minor shifts over time. In DJF (Figure 4a-e), the ITCZ mainly covered the SH tropical latitudes between $0^{\circ}-$ $20^{\circ} \mathrm{S}$ from southern Africa to the tropical West Pacific. In JJA (Figure $4 \mathrm{f}-\mathrm{j}$ ), on the other hand, the ITCZ was located in the NH tropical latitudes between $0^{\circ}-20^{\circ} \mathrm{N}$ from northern Africa to the West Pacific. It should be noted that, although the position of the ITCZ was relatively stable throughout the Cenozoic, at different geological periods it still covered different regions over the land masses due to the motion of the tectonic plates. For example, in mid-Paleocene the Indian Subcontinent was located in the tropical SH and under the control of the ITCZ in DJF (Figure 4a). Since the Eocene, however, its seasonality under the control of the ITCZ was switched to JJA because it moved into the tropical NH (Figure $4 \mathrm{~g}-\mathrm{j}$ ). Similarly, Australia was positioned in the SH midlatitudes before the Miocene and entirely out of the influence of the ITCZ (Figure 4a-c). In the lateMiocene, the most northern part of Australia moved into the SH tropical latitudes (Figure 4d), while only in the present day did northern Australia become influenced by the ITCZ during DJF (Figure $4 \mathrm{e})$.

Based on the above analysis, we defined the regions directly under the control of the ITCZ as those of mean seasonal upward motion with $\omega<-0.015 \mathrm{~Pa} \mathrm{~s}^{-1}$, so that we can compare its positions with the locations of the monsoon regions (Figure 5). There is no doubt that the existence of monsoon regions is closely related to the activities of the ITCZ. For any specific region, only the summer is influenced by the ITCZ to form the rainy season, while the winter becomes the dry season as the ITCZ migrates into the other hemisphere, and such alternating seasonality would create a typical tropical monsoon climate. Therefore, monsoon regions do not exist in regions where the ITCZ cannot reach and those with year-round influence of the ITCZ have persistent wet conditions throughout the year. For example, in the mid-Paleocene (Figure 5a), the ITCZ covered the northern African and southern Asian monsoon regions during JJA at the rainy season. When the ITCZ migrated to the SH in DJF, it covered the southern Africa and the Indian Subcontinent, making them into the SH tropical monsoon regions. In the Eocene (Figure 5b), the Indian Subcontinent was under the influence of the ITCZ after it moved into the NH tropical latitudes, and thereby significantly increased the size of the South Asian monsoon region. Australia continued its move northward during the Cenozoic, but only at the late-Miocene did its northern end move into the SH tropical latitudes and began to be influenced by the ITCZ (Figure $5 \mathrm{~d}$ and 5e), which initiated the monsoon region in Australia. This timing matched the results from Miller et al. (2017): west Australia (current latitude $\sim 23.5^{\circ} \mathrm{S}$ ) reached $\sim 30^{\circ} \mathrm{S}$ at approximately $10 \mathrm{Ma}$. Throughout the Cenozoic, northern and southern Africa had been influenced by the ITCZ during their respective summer seasons (Figure 5) 
and, therefore, monsoon regions existed there persistently with only minor changes in size (Figure $3 \mathrm{a}$ and $3 \mathrm{~b}$ ). In summary, the monsoon regions in northern and southern Africa, South Asia, and northern Australia all belong to the tropical monsoon regions and their existence is result of the seasonal migration of the ITCZ. The only exception is the East Asian monsoon region. Since its appearance in the Miocene, its northern boundary extended beyond the NH tropical latitudes and the most northern latitude of the ITCZ migration (Figure $5 \mathrm{~d}$ and 5e). Therefore, the existence of the subtropical East Asian monsoon region is not the consequence of the seasonal migration of the ITCZ.

Because of the uniqueness of the East Asian monsoon, we specifically analyzed the evolutionary process of the northward expansion of the summer monsoon circulation (Figure 6). The most northern position of the northward warm and humid winds from the tropical ocean can be regarded as the northern boundary of the East Asian summer monsoon. At $60 \mathrm{Ma}$, the East Asian summer monsoon could only reach the coast of South China at $\sim 26^{\circ} \mathrm{N}$ (Figure 6a). At $40 \mathrm{Ma}$, it pushed to the north to $\sim 30^{\circ} \mathrm{N}$ (Figure 6b), and then further north to $32^{\circ} \mathrm{N}$ (Figure 6c) and $38^{\circ} \mathrm{N}$ (Figure 6d) at $25 \mathrm{Ma}$ and $10 \mathrm{Ma}$, respectively. The northern boundary of the present-day East Asian summer monsoon can reach to $\sim 42^{\circ} \mathrm{N}$ (Figure 6e). Correspondingly, the East Asian monsoon-rain belt has moved northward with the summer monsoon circulation (Figure $6 \mathrm{f}-6 \mathrm{j}$ ) since the Eocene. Under the influence of the ITCZ, the latitude of peak rainfall was located in $5^{\circ} \mathrm{S}$ at $40 \mathrm{Ma}$ (Figure $6 \mathrm{~g}$ ), but shifted to $10^{\circ} \mathrm{N}$ (Figure 6h) and $15^{\circ} \mathrm{N}$ (Figure 6i) at $25 \mathrm{Ma}$ and $10 \mathrm{Ma}$, respectively, while the present-day rainfall peak occurred at $15^{\circ}-20^{\circ} \mathrm{N}$ (Figure $6 \mathrm{j}$ ). It is worth noting that since the Miocene, in response to the development of the summer monsoon circulation in the northern part of East Asia, the subtropical East Asian $\left(20^{\circ}-40^{\circ} \mathrm{N}\right)$ summer rainfall continued to increase (Figure $6 \mathrm{i}$ and $6 \mathrm{j}$ ). In the meantime, according to the direction of moisture transport indicated by rainfall gradient, the present-day rainfall gradient at $35^{\circ}-40^{\circ} \mathrm{N}$ decreases from south to north, which means that the increased rainfall at $40^{\circ} \mathrm{N}$ of East Asia is derived from the southerly summer monsoon winds. In contrast to the present-day pattern, the Eocene $35^{\circ}-40^{\circ} \mathrm{N}$ rainfall gradient is from north to south with a peak at $45^{\circ} \mathrm{N}$ (Figure $6 \mathrm{~g}$ ), which means that the increased precipitation around $40^{\circ} \mathrm{N}$ resulted from the expansion of the mid-latitude rain belt under the condition of high $\mathrm{CO}_{2}$ concentration, not from the northward transport of tropical-ocean moisture by the East Asian summer monsoon circulation. Therefore, in the extratropical region, it would not have provided a full picture of the evolution of the monsoon if we only used the rainfall amount to define the spatial range of monsoon activities and it is necessary to consider the characteristics of the atmospheric circulation. Additionally, the analysis in Section 5 below will further confirm the connection between the uplift of the Tibetan Plateau and the evolution of the monsoon climate in the northern part of East Asia.

\subsection{Distributions of arid regions and the positions of the subtropical high pressures}

Studies of modern climatology have indicated that the continental or global scale distribution of arid regions is very much linked to the $\mathrm{NH}$ and SH subtropical high pressure (STH hereafter) zones $\left(20^{\circ}-40^{\circ} \mathrm{S}\right.$ and $\left.20^{\circ}-40^{\circ} \mathrm{N}\right)$ produced by the descending limb of the Hadley Cell north and south of the equator (McIlveen, 2010). The compression and warming of the descending air creates dry and stable conditions that lead to the development of the arid climate under the control of the STH anticyclones. In order to examine the time evolution of the Cenozoic A-A-A arid regions in relation to the STH's, we analyzed sea level pressure (SLP) fields during the 5 geological periods (Figure 7). Our results showed that except for the Asian interior, all arid regions were under the control of the STH's during these different geological periods. For example, in the mid-Paleocene 
(Figure 7a), the annual mean NH STH zone was centered at $30^{\circ} \mathrm{N}$ and covered a broad belt from North Africa to East Asia, including the arid regions in Asia and the northwest margin of North Africa. Similarly, the SH STH was centered at $30^{\circ} \mathrm{S}$ and encompassed the southern African arid region. Australia was still positioned in the SH mid-latitude region and not influenced by the $\mathrm{SH}$ STH's, and therefore did not have any arid region. In the late-Eocene (Figure 7b) and late-Oligocene (Figure 7c), as the African continent moved somewhat northward, the northern part of North Africa was close to the center of the NH STH zone and the arid region there expanded. In the meantime, the SH STH zone is centered near the southern end of the African continent, which caused the arid region in South Africa to reduce in size. The arid region in Asia was still under the control of the STH's, but because of the uplift and northward shift of the Tibetan Plateau, the STH zone north of the Plateau became narrower. However, as the Indian Subcontinent joined Asia, the Asian continent enlarged its size, which also increased the area of the Asian STH arid lands. In the late-Miocene (Figure 7d), as the Tibetan Plateau continued to uplift and move to the north, the rain-barrier effect of topography was enhanced for the Asian interior, together with the dynamic descending motion of the air north of the Tibetan Plateau (Shi et al., 2011) to promote the formation of a high pressure system, causing the northward expansion of the Asian interior arid region to approximately $40^{\circ} \mathrm{N}$. From this point, the high pressure system associated with the arid region in the Asian interior did not belong to the STH system any more as the Asian interior arid region further expanded northward. In the late-Miocene, the majority of Australia moved into the SH subtropical latitudes, which led to the expansion of the Australian arid region under the influence of the STH's. Up to the present day (Figure 7e), arid regions in Central Asia and Asian interior north of the Tibetan Plateau further expanded, while the arid region in Australia reduced in size as the Australian continent moved northward, causing the weakening influence of the SH STH's.

In order to visually observe the changes in the Hadley Cell that are closely related to the STH's, we plotted the mean annual meridional streamfunction for the 5 Cenozoic geological periods for the zonal mean and sectorial mean over Asia (Figure 8), as used in meteorological studies (Webster, 2004). Our results showed that the mean annual zonally averaged Hadley circulation remained relatively stable throughout the Cenozoic (left column of Figure 8). Near the equator are the ascending limbs of the Hadley Cell, while the descending limbs occurred near $30^{\circ} \mathrm{N}$ and $30^{\circ} \mathrm{S}$, corresponding to the STH zones in the SLP field and arid regions. However, across the longitudes of the Asian continent $\left(70^{\circ}-120^{\circ} \mathrm{E}\right)$, while the Cenozoic Hadley circulation remained stable in the $\mathrm{SH}$, the NH Hadley circulation showed significant changes (right column of Figure 8). At $60 \mathrm{Ma}$, there was a complete Hadley Cell in the NH, while the NH Hadley circulation only existed in the mid- and high-troposphere at $40 \mathrm{Ma}$. After $25 \mathrm{Ma}$, the NH Hadley Cell was further compressed and the ascending flow appeared in the lower troposphere of the NH subtropical latitudes. The presentday ascending flow further extended to the upper troposphere in the subtropical Asia. In fact, it is the development of the Asian monsoons that caused the changes in the regional Hadley circulation and altered the arid conditions in the East Asian subtropical region. From the seasonal averages, it can be seen that the changes in the vertical motion over Asia in the Cenozoic mainly occurred in summer rather than winter. The winter season averages of vertical velocity (left column of Figure 9) showed persistent descending motion over the Asian continent. While the winter descending motion was limited to the subtropical latitudes $\left(20^{\circ}-40^{\circ} \mathrm{N}\right)$ in $60 \mathrm{Ma}$, it continued to expand afterward, reaching to $10^{\circ}-50^{\circ} \mathrm{N}$ in the present day. On the other hand, the summer averages of vertical velocity (right column of Figure 9) showed continued expansion of the ascending motion, 
from the tropical latitudes toward the subtropical and mid-latitude regions. At $60 \mathrm{Ma}$, the ascending motion was found between $10^{\circ} \mathrm{S}$ and $20^{\circ} \mathrm{N}$. Afterward, it expanded to $10^{\circ} \mathrm{S}-30^{\circ} \mathrm{N}$ at $25 \mathrm{Ma}$ and then further to $0^{\circ}-50^{\circ} \mathrm{N}$ in the present day. With the northward expansion of ascending region, the STH and the descending region to the north were compressed and pushed to the north. For example, the descending motion was located in $20^{\circ}-40^{\circ} \mathrm{N}$ at $60 \mathrm{Ma}$, while in the present day, it was only seen in a small area near $50^{\circ} \mathrm{N}$. This matched the development of the high pressure system and Asian interior arid region north of the Tibetan Plateau (Figure 7e). This means that the Cenozoic mean annual meridional circulation in Asia was mostly determined by the changes in the summer circulation. As indicated by the analysis on the horizontal and vertical circulations, except for the Asian interior arid region, the existence of the major arid regions in the A-A-A realm can be attributed to the mean annual STH zones. Even though the latitudes under the control of the STH's did not change much throughout the Cenozoic, the regions under the influence of the STH's changed with the continental drift, which led to the changes in specific arid regions. It should be pointed out that the uplift of the Tibetan Plateau was critical to the development of the arid region of the interior Asia, while the evolution of the arid regions in northern Africa and West Asia was closely related to the regional changes in the land-ocean configuration. In the following, we will further explore the relationship between the tectonic boundary condition and evolution of the arid regions.

\section{Relationships of Cenozoic evolution of A-A-A monsoon and arid regions with continental drift and Tibetan Plateau uplift}

The previous analysis has indicated that the semi-permanent general circulation systems, such as the ITCZ and STH's, are the main causes for the formations of the tropical monsoon and subtropical arid regions respectively. However, to fully understand the Cenozoic evolutionary histories of the A-A-A monsoon and arid regions, we need to consider the changes in the tectonic boundary conditions, such as the continental drift and uplift of the Tibetan Plateau. In order to isolate the effects of the plateau uplift, we examined the results of the second set of comparative experiments (without topography). It was discovered that from the late-Eocene to present day (Figure 10a-d), the tropical monsoon regions $\left(20^{\circ} \mathrm{S}-20^{\circ} \mathrm{N}\right)$ existed in northern and southern Africa, South Asia, and northern Australia (since the late-Miocene). Similarly, the STH arid regions also existed in northern and southern Africa, West Asia, and Australia (since the late-Miocene). Compared to the experiments with topography, the major difference is the complete disappearance of the East Asian monsoon north of $20^{\circ} \mathrm{N}$ from the late-Miocene (Figure 10c) to the present day (Figure 10d) in the no-topography experiments. This is a drastic contrast to the simulation results with the uplift of the Tibetan Plateau, showing the northward expansion of the East Asian monsoon region to $38^{\circ} \mathrm{N}$ in the late-Miocene (Figure $2 \mathrm{~d}$ ) and then to $42^{\circ} \mathrm{N}$ in the present day (Figure 2e). The other set of comparative experiments (the set with different $\mathrm{CO}_{2}$ concentrations) examined the effects of the Eocene $\mathrm{CO}_{2}$ concentration. Under the same tectonic boundary condition of $40 \mathrm{Ma}$ land-ocean configuration and topography, the average global mean annual temperature was $19.22^{\circ} \mathrm{C}$ and $26.77^{\circ} \mathrm{C}$ for the $1 \mathrm{x}$ and $4 \times \mathrm{CO}_{2}$ concentration, respectively. In other words, the increased $\mathrm{CO}_{2}$ concentration can cause an increase in global mean temperature by $7.55^{\circ} \mathrm{C}$ under the same lateEocene tectonic boundary conditions. With the same late-Eocene land-ocean configuration, for the conditions of plateau uplift with $1 \times$ (Figure 10e) and $4 \times \mathrm{CO}_{2}$ (Figure 2b), or the conditions of no plateau topography with $1 \times$ (Figure 10f) and $4 \times \mathrm{CO}_{2}$ (Figure 10a), almost no change occurred to the distributions of the monsoon and arid regions. These comparative experiments clearly indicate 
that it is the plateau uplift, rather than increased $\mathrm{CO}_{2}$ concentration, that created the East Asian monsoon region and the Asian interior arid region north of $40^{\circ} \mathrm{N}$. Inversely, the decrease in $\mathrm{CO}_{2}$ concentration after the Eocene and the corresponding global cooling should also not be the main cause for the formation of the mid-latitude Asian interior arid region. In contrast, the evolution of the tropical monsoon and subtropical arid regions were mainly the consequence of the continental drift and changes in the land-ocean configuration.

By analyzing the changes in the sizes of the Asian monsoon and interior arid regions with the changing Cenozoic topographic characteristics of the Tibetan Plateau, we can better observe the linkage between them. The Tibetan Plateau has continued to uplift since the Eocene, with increasing size and northward movement. For example, if we define the plateau as the area with elevations above $1,500 \mathrm{~m}$, at $40 \mathrm{Ma}$ its average elevation was $2700 \mathrm{~m}$ with a size of $1,700,000 \mathrm{~km}^{2}$ centered at $18.5^{\circ} \mathrm{N}$. At the present day, its average elevation reached $4,200 \mathrm{~m}$ with a size of $2,500,000 \mathrm{~km}^{2}$ centered at $33.9^{\circ} \mathrm{N}$ (Figure 11a). The total area of the Asian monsoon regions has generally increased with the plateau uplift, but not following a linear trend. Even before the plateau uplift in $60 \mathrm{Ma}$, the area of the Asian monsoon region was $3,000,000 \mathrm{~km}^{2}$, reflecting the presence of the tropical monsoon in Southeast Asia. At $10 \mathrm{Ma}$, the mean plateau elevation had exceeded 3,500 m, approximately $85 \%$ of its modern height, with an average latitude near $30^{\circ} \mathrm{N}$. Correspondingly, the area of the Asian monsoon region, increased significantly since the Miocene and exceeded $10,000,000 \mathrm{~km}^{2}$ at the present day. This has mostly resulted from the plateau uplift and its northward shift, causing the East Asian monsoon (Figure 2d and 2e), specifically the East Asian summer monsoon (Figure 6), to expand to the mid-latitude region. In this process, the enhanced thermal effect of the plateau due to its uplift has played an important role (Liu and Yin, 2002, Wu et al., 2012). The uplift and northward motion of the Tibetan Plateau were also the major cause for the formation of the Asian interior arid region north of the plateau. The central latitude of the plateau was located at $18.7^{\circ} \mathrm{N}, 29.8^{\circ} \mathrm{N}$, and $34.1^{\circ} \mathrm{N}$ in $40 \mathrm{Ma}, 10 \mathrm{Ma}$, and 0 Ma respectively, representing a northward shift for the plateau center by more than $15^{\circ}$ from the late-Eocene to the present day (Figure 11b). Prior to the Oligocene, the Tibetan Plateau was located mostly south of $30^{\circ} \mathrm{N}$ and only since the Miocene has the main body of the plateau been located north of $30^{\circ} \mathrm{N}$. In $10 \mathrm{Ma}$ and the present day, the plateau area north of $30^{\circ} \mathrm{N}$ grew to $1,400,000 \mathrm{~km}^{2}$ and $2,200,000 \mathrm{~km}^{2}$ respectively. With the plateau uplift, especially the uplift north of $30^{\circ} \mathrm{N}$, the arid region north of the plateau developed in response, reaching $600,000 \mathrm{~km}^{2}$ and $1,600,000 \mathrm{~km}^{2}$ in $10 \mathrm{Ma}$ and present day respectively. These results, which include the effects of continental drift, further confirm the earlier results which did not consider continental drift, that the Tibetan Plateau uplift played a determinant role for the development of the mid-latitude Asian interior arid region (Manabe and Broccoli, 1990, Liu et al., 2015a).

Changes in the regional land-ocean configuration are closely related to the evolution of subtropical arid regions. For example, in the mid- to low-latitude A-A-A realm $\left(20^{\circ} \mathrm{W}-100^{\circ} \mathrm{E}\right.$, $20^{\circ} \mathrm{N}-60^{\circ} \mathrm{N}$ ), the land-ocean configuration changed dramatically during the Cenozoic. At $60 \mathrm{Ma}$, the areas of the land mass and ocean were $18,000,000 \mathrm{~km}^{2}$ and 26,000,000 $\mathrm{km}^{2}$ respectively (Figure $11 \mathrm{c})$, a $40 \%$ to $60 \%$ split between land and ocean. With the retreat of the Paratethys Sea, the area of land mass increased while the area of ocean decreased. The present-day distribution of land and ocean in the same region is roughly $36,000,000 \mathrm{~km}^{2}$ and $8,000,000 \mathrm{~km}^{2}$, with an $80 \%$ to $20 \%$ split between land and ocean. With increasing size of the land mass, the size of the arid regions (including North Africa, Arabian Peninsula, West Asia, and Central Asia) increased correspondingly. It is 
interesting to note that there was a jump in the total area of the arid regions between $40 \mathrm{Ma}$ and 25 Ma (Figure 11c), which more than tripled in size from 3,500,000 $\mathrm{km}^{2}$ to nearly $11,000,000 \mathrm{~km}^{2}$. Afterward, there were only relatively minor changes, which suggests that the relationship between the size of the arid regions and the regional land-ocean configuration was also nonlinear, with the changes from the late-Eocene to late-Oligocene as the most dramatic.

The northward movement of the Australian continent is the cause of the formation and development of the Australian monsoon and arid regions during the Cenozoic. Previous analysis has already indicated that the tropical monsoon climate is the consequence of the seasonal influence of the ITZC that migrates between $20^{\circ} \mathrm{N}$ and $20^{\circ} \mathrm{S}$. As the Australian continent moved northward during the Cenozoic, the most northern latitude of Australia reached north of $20^{\circ} \mathrm{S}$ in $10 \mathrm{Ma}$ (Figure 11d). Since then, northern Australia moved into the tropical SH and began to develop a monsoon climate under the influence of the ITCZ. The most northern latitude of the present-day Australian continent was $10.8^{\circ} \mathrm{S}$ and the Australian monsoon region reached its maximum size. On the other hand, in $10 \mathrm{Ma}$ the center latitude of the Australian continent was close to $30^{\circ} \mathrm{S}$, which was also the center location of the SH STH zone with its maximum influence. Therefore, that was when the Australian arid region reached its maximum size (close to 5,000,000 $\mathrm{km}^{2}$ ). Prior to the Miocene, because the Australian continent was located in the mid-latitude SH and not influenced by the SH STH's, there did not exist any arid region. Since the late-Miocene, as the Australian continent further moved northward, the area influenced by the SH STH's decreased and the area of the arid region was reduced to less than $1,500,000 \mathrm{~km}^{2}$.

\section{Discussion and Conclusions}

Geological evidence has shown that major changes have occurred to monsoon and arid environments in the A-A-A realm, the land-ocean configuration of the Eastern Hemisphere, and the topography of the Tibetan Plateau since the beginning of the Cenozoic. Motivated by this background, we systemically explored the formation and evolutionary processes of the Cenozoic AA-A monsoon and arid regions under the influences of continental drift and plateau uplift based on climate simulation results for five typical geological periods using a coupled ocean-atmosphere GCM. Our results suggest that the timings and the formation mechanisms of the monsoon and arid regions in the A-A-A realm were very different. The northern and southern African monsoon existed in the mid-Paleocene and the South Asian monsoon appeared when the Indian Subcontinent moved into the NH in the Eocene, while the northern East Asian and northern Australian monsoons were established in the Miocene.

The establishment of the tropical monsoons in northern and southern Africa and tropical Australia was achieved by both continental drift and seasonal migration of the ITCZ. In the meantime, the presence of the subtropical arid regions in northern and southern Africa, Asia, and Australia was determined by the positions of the continents and the planetary-scale mean annual subtropical high pressure systems. Our study emphasizes the direct controlling effects of the ITCZ and subtropical high pressure systems on the formation and evolution of the tropical monsoon and subtropical arid regions. Throughout the entire Cenozoic, latitudinal ranges of these planetary-scale circulation systems were relatively stable. Since the African continent did not move much during the Cenozoic, the locations of the monsoon and arid regions in northern and southern Africa were also relatively stable. Even though the ranges of the ITCZ and STH's did not change much during the Cenozoic, the regions in the Indian Subcontinent and Australian continent under the influence 
of ITCZ and STH's changed as the Indo-Australian Plate moved northward dramatically over time, which led to the changes in the South Asian monsoon region and the Australian monsoon and arid regions. The development of the arid regions in the Arabian Peninsula and West Asia was closely related to the changes in the regional land-ocean configuration, especially the shrinkage of the Paratethys Sea. Beside the determinant effects of the planetary-scale atmospheric circulation systems, such as ITCZ and STH's, on the formations and evolutions of the tropical monsoon and subtropical arid regions under the changing tectonic boundary conditions, we should not exclude the possibility that there may have existed certain coupled interactions between the development of the monsoon and arid climates in certain regions (Rodwell and Hoskins, 1996; Wu et al., 2009), especially the forcing of the diabatic warming by the Asian monsoons to cause Rossby waves to form to the west and the corresponding adiabatic descent to enhance the aridity around the Mediterranean and Central Asian regions.

The establishment of the extratropical monsoon in northern East Asia and formation of the mid-latitude arid region of the Asian interior were closely related to the uplift and change in position of the Tibetan Plateau as these cannot be attributed to the influences of the ITCZ and STH's. It is the uplift of the Tibetan Plateau and its horizontal expansion and northward shift that caused the northward expansion of the East Asian summer monsoon to North China since the Miocene, signaling the origin and development of the northern East Asian monsoon. In contrast, the presence of the South Asian monsoon is not the consequence of the plateau uplift, when the effects of continental drift are taken into account. This is similar to the results in Liu and Yin (2002) where the effects of continental drift were not considered, which showed that the East Asian monsoon is more sensitive to the plateau uplift than the South Asian monsoon. Our results also showed that without the plateau topography, even the $4 \times \mathrm{CO}_{2}$ during the Eocene could not promote the establishment of the extratropical monsoon in East Asia. Therefore, we conclude that the uplift of the Tibetan Plateau, rather than high atmospheric $\mathrm{CO}_{2}$ concentration, served as the determining factor for the origin of the northern East Asian monsoon, differing from the conclusions of Licht et al. (2014). On the other hand, as the Tibetan Plateau continued its uplift and northward shift during the Cenozoic, the mean elevation reached $85 \%$ of its modern height in the late-Miocene, with its main body north of $30^{\circ} \mathrm{N}$. This caused the formation of the dynamic high pressure system near $40^{\circ} \mathrm{N}$ north of the plateau, as well as the formation and northward expansion of the mid-latitude arid region of the Asian interior. Again, the effects of the plateau topography and its northward shift caused the development of the Asian interior arid region to break away from the constraint of the STH's.

Our simulations which include the effects of the changes in tectonic boundary conditions, including the Cenozoic continental drift and plateau uplift, qualitatively matched the geological evidence reflecting the evolutionary histories of the A-A-A monsoon and arid regions. For example, the origin of the South Asian monsoon can be traced back to the Eocene (Shukla et al., 2014; Spicer et al., 2017), while the northern East Asian monsoon associated with the alteration of the East Asian atmospheric circulation only appeared in the Miocene (Guo et al., 2002; Sun and Wang 2005). Due to the drastic differences among the evolutionary histories of the different monsoon regions, we recognize the limitation of applying the concept of a global monsoon based on modern observations to the tectonic time scale. Similarly, Caley et al. (2017) also noticed that, at the orbital time scale, the responses of monsoon climates to the earth's orbital forcing differed among different regions. In terms of the evolution of the arid regions, there existed a broad zonal arid belt in China during the Paleogene (Guo et al., 2008) and the unique Asian "inland desert" did not form until the Miocene 
(Guo, 2017). The arid region of central Australia and the northern Australian monsoon region both appeared in the Miocene, as well as the differentiation of the monsoon and arid regions (Marin et al., 2013). Our simulations indicated that monsoon and arid regions existed in northern and southern Africa throughout the Cenozoic, but this result has yet to be supported by geological evidence.

Although the simulations in our study portrayed the formations and evolutionary histories of the A-A-A monsoon and arid regions during Cenozoic well, we recognize that there were certain uncertainties. For example, the climate model (FAMOUS AOGCM) used in this study has relatively low spatial resolution and biases in certain regional climate elements, such as precipitation, which may have impacted its ability to accurately delineate the monsoon and arid regions. The Cenozoic tectonic boundary condition, such as the land-ocean configurations, paleotopography and elevations, and atmospheric $\mathrm{CO}_{2}$ concentrations in different geological periods were based on the integration of published geological evidence from multiple sources. These geological records have a range of uncertainties and different spatial resolutions, and sometimes contradict each other. Therefore, more accurate simulations will depend to a large extent on more reliable reconstructions of the boundary conditions. Beside the land-ocean configuration and paleotopography, other surface conditions may also have significant influences on the distributions of the monsoon and arid regions. For example, development of the polar ice caps may modulate the position of the ITCZ (Chiang and Bitz, 2005) and further influence the tropical monsoons, while the formation of the sandy deserts may enhance aridification (Liu et al. 2015b). Therefore, these modifications to the boundary conditions should be considered in future studies. In order to promote better comparative analysis between model simulation results and geological records, it is necessary to further explore how to use metrics reflecting variation in moisture conditions of the climate to quantitatively delineate the ranges of monsoon and arid regions. In summary, the formation and evolution of the Cenozoic monsoon and arid regions are the consequences of the interactions among the different spheres of the earth system, which will remain as an important scientific question that requires further investigation from the perspectives of interdisciplinary approach in the future.

Acknowledgements The authors sincerely thank the anonymous reviewers who provided valuable comments and suggestions that helped revision of the manuscript. This work was jointly supported by the Strategic Priority Research Program of Chinese Academy of Sciences (XDA20070103) and the National Natural Science Foundation of China (41690115 and 41572150). BD, and RSS were supported by the U.K. National Centre for Atmospheric Science-Climate (NCAS-Climate) at the University of Reading.

\section{References}

An Z S, Kutzbach J E, Prell W L, Porter S C. 2001. Evolution of Asian monsoons and phased uplift of the Himalaya-Tibetan plateau since Late Miocene times. Nature, 411: 62-66

An Z S. 2000. The history and variability of the East Asian paleomonsoon climate. Quat Sci Rev, 19: $171-187$

Beerling D J, Royer D L. 2011. Convergent Cenozoic $\mathrm{CO}_{2}$ history. Nat Geosci, 4: 418-420

Berry G, Reeder M J. 2014. Objective identification of the intertropical convergence zone: Climatology and trends from the ERA-Interim. J Climate, 27: 1894-1909 
Besse J, Courtillot V, Pozzi J P, Westphal M, Zhou Y X. 1984. Palaeomagnetic estimates of crustal shortening in the Himalayan thrusts and Zangbo suture. Nature, 311: 621-626

Bobe R. 2006. The evolution of arid ecosystems in eastern Africa. J Arid Environ, 66: 564-584

Bosboom R, Dupont-Nivet G, Grothe A, H Brinkhuis, Villa G, Mandic O, Stoica M, W Huang, Yang W, Guo Z. 2014. Linking Tarim Basin sea retreat (west China) and Asian aridification in the late Eocene. Basin Res, 26: 621-640

Bowler J M, Wyrwoll K H, Lu Y. 2001. Variations of the northwest Australian summer monsoon over the last 300,000 years: the paleohydrological record of the Gregory (Mulan) Lakes System. Quaternary Int, 83-85: 63-80

Caley T, Malaizé B, Revel M, Ducassou E, Wainer K, Ibrahim M, Shoeaib D, Migeon S, Marieu V. 2011. Orbital timing of the Indian, East Asian and African boreal monsoons and the concept of a 'global monsoon'. Quat Sci Rev, 30: 3705-3715

Carrapa B, Huntington K W, Clementz M, Quade J, Bywater-Reyes S, Schoenbohm L M, Canavan R R. 2014. Uplift of the Central Andes of NW Argentina associated with upper crustal shortening, revealed by multiproxy isotopic analyses. Tectonics, 33: 1039-1054

Caves J K, Moragne D Y, Ibarra D E, Bayshashov B U, Gao Y, Jones M M, Zhamangara A, Arzhannikova A V, Arzhannikov S G, Chamberlain C P. 2016. The Neogene de-greening of Central Asia. Geology, 44: 887-890

Chatterjee S, Goswami A, Scotese C R. 2013. The longest voyage: Tectonic, magmatic, and paleoclimatic evolution of the Indian plate during its northward flight from Gondwana to Asia. Gondwana Research, 23: 238-267

Chiang J C H, Bitz C M. 2005. Influence of high latitude ice cover on the marine Intertropical Convergence Zone. Clim Dyn, 25: 477-496

Colin C, Siani G, Liu Z, Blamart D, Skonieczny C, Zhao Y, Bory A, Frank N, Duchamp-Alphonse S, Thil F. 2014. Late Miocene to early Pliocene climate variability off NW Africa (ODP Site 659). Palaeogeogr Palaeoclim Palaeoecol, 401: 81-95

DeCelles P G, Quade J, Kapp P, Fan M, Dettman D L, Ding L. 2007. High and dry in central Tibet during the Late Oligocene. Earth Planet Sci Lett, 253: 389-401

Demenocal P B. 1995. Plio-pleistocene African climate. Science, 270: 53-59

Dettman D L, Fang X M, Garzione C N, Li J J. 2003. Uplift-driven climate change at 12 Ma: a long $\delta^{18} \mathrm{O}$ record from the NE margin of the Tibetan plateau. Earth Planet Sci Lett, 214: 267-277

Ding L, Xu Q, Yue Y, Wang H, Cai F, Li S. 2014. The Andean-type Gangdese Mountains: Paleoelevation record from the Paleocene-Eocene Linzhou Basin. Earth Planet Sci Lett, 392: 250-264

Ding Z L, Rutter N, Han J T, Liu T S. 1992. A coupled environmental system formed at about 2.5 Ma in East Asia. Palaeogeogr Palaeoclim Palaeoecol, 94: 223-242

Fan M, Carrapa B. 2014. Late Cretaceous-early Eocene Laramide uplift, exhumation, and basin subsidence in Wyoming: Crustal responses to flat slab subduction. Tectonics, 33: 509-529

Fang X M, Zan J B, Appel E, Lu Y, Song C H, Dai S, Tuo S B. 2015. An Eocene-Miocene continuous rock magnetic record from the sediments in the Xining Basin, NW China: indication for Cenozoic persistent drying driven by global cooling and Tibetan Plateau uplift. Geophys J Int, 201: 78-89

Fujioka T, Chappell J. 2010. History of Australian aridity: chronology in the evolution of arid landscapes. Geol Soc London Spec Publ, 346: 121-139 
Gadgil S. 2003. The Indian monsoon and its variability. Ann Rev Earth Planet Sci. 31: 429-467

Gadgil S. 2018. The monsoon system: Land-sea breeze or the ITCZ? J Earth Syst Sci, 127: 1-29

Guo Z T, Ruddiman W F, Hao Q Z, Wu H B, Qiao Y S, Zhu R X, Peng S Z, Wei J J, Yuan B Y,

Liu T S. 2002. Onset of Asian desertification by $22 \mathrm{Myr}$ ago inferred from loess deposits in China. Nature, 416: 159-163

Guo Z T, Sun B, Zhang Z S, Peng S Z, Xiao G Q, Ge J Y, Hao Q Z, Qiao Y S, Liang M Y, Liu J F. 2008. A major reorganization of Asian climate by the early Miocene. Clim Past, 4: 153-174

Guo Z T. 2017. Loess Plateau attests to the onsets of monsoon and deserts (in Chinese). Scientia Sinica Terrae, 47: 421-437

Gupta A K, Yuvaraja A, Prakasam M, Clemens S C, Velu A. 2015. Evolution of the South Asian monsoon wind system since the late Middle Miocene. Palaeogeogr Palaeoclim Palaeoecol, 438: $160-167$

Gurnis M, Turner M, Zahirovic S, DiCaprio L, Spasojevic S, Müller R D, Boyden J, Seton M, Manea V C, Bower D J. 2012. Plate tectonic reconstructions with continuously closing plates. Comput Geosci-UK, 38: 35-42

Hall R. 2002. Cenozoic geological and plate tectonic evolution of SE Asia and the SW Pacific: computer-based reconstructions, model and animations. J Asian Earth Sci, 20: 353-431

Herold N, Seton M, Müller R D, You Y, Huber M. 2008. Middle Miocene tectonic boundary conditions for use in climate models. Geochemistry Geophysics Geosystems, 9: 1-10

Huber M, Goldner A. 2012. Eocene monsoons. J Asian Earth Sci, 44: 3-23

Jones C, Gregory J, Thorpe R, Cox P, Murphy J, Sexton D, Valdes P. 2005. Systematic optimisation and climate simulation of FAMOUS, a fast version of HadCM3. Clim Dyn, 25: 189-204

Kakhki A N, Aliabadian M, Schweizer M. 2016. Out of Africa: biogeographic history of the openhabitat chats (Aves, Muscicapidae: Saxicolinae) across arid areas of the old world. Zool Scr, 45: $237-251$

Kroon D. 1991. Onset of monsoonal related upwelling in the western Arabian Sea as revealed by planktonic foraminifers. Proc Ocean Drill Prog Sci Res, 117: 257-263

Kutzbach J E, Prell L, Ruddiman W F. 1993. Sensitivity of Eurasian climate to surface uplift of the Tibetan Plateau. J Geol, 101: 177-190

Läderach A, Raible C C. 2013. Lower-tropospheric humidity: climatology, trends and the relation to the ITCZ. Tellus A, 65: 20413

Li J X, Yue L P, Roberts A P, Hirt A M, Pan F, Guo L, Xu Y, Xi R G, Guo L, Qiang X K, Gai C C, Jiang Z X, Sun Z M, Liu Q S. 2018a. Global cooling and enhanced Eocene Asian mid-latitude interior aridity. Nature Comm, 9: 3026

Li X Y, Zhang R, Zhang Z S, Yan, Q. 2018b. What enhanced the aridity in Eocene Asian inland: Global cooling or early Tibetan Plateau uplift? Palaeogeogr Palaeoclim Palaeoecol, 510, 6-14.

Licht A, Cappelle M V, Abels H A, Ladant J B, Trabuchoalexandre J, Francelanord C, Donnadieu Y, Vandenberghe J, Rigaudier T, Lécuyer C. 2014. Asian monsoons in a late Eocene greenhouse world. Nature, 513: 501-506

Linder H P, 2017. East African Cenozoic vegetation history. Evolutionary Anthropology: Issues, News, and Reviews, 26: 300-312

Liu X D, Dong B W, Yin Z Y, Smith R S, Guo Q C. 2017. Continental drift and plateau uplift control origination and evolution of Asian and Australian monsoons. Sci Rep, 7: 40344 
Liu X D, Guo Q C, Guo Z T, Yin Z Y, Dong B W, Smith R S. 2015a. Where were the monsoon regions and arid zones in Asia prior to the Tibetan Plateau uplift? Natl Sci Rev, 2: 403-416

Liu X D, Sun H, Miao Y F, Dong B W, Yin Z Y. 2015b. Impacts of uplift of northern Tibetan Plateau and formation of Asian inland deserts on regional climate and environment. Quat Sci Rev, 116: 1-14

Liu X D, Yin Z Y. 2002. Sensitivity of East Asian monsoon climate to the uplift of the Tibetan Plateau. Palaeogeogr Palaeoclim Palaeoecol, 183: 223-245

Liu T S, 1985. Loess and Environment. China Ocean Press, Beijing, 1-234

Lu H Y, Guo Z T. 2014. Evolution of the monsoon and dry climate in East Asia during late Cenozoic: A review. Sci China Earth Sci, 57: 70-79

Manabe S, Broccoli A J. 1990. Mountains and arid climates of middle latitudes. Science, 247: 192195

Marin J, Donnellan S C, Hedges S B, Doughty P, Hutchinson M N, Cruaud C, Vidal N. 2013. Tracing the history and biogeography of the Australian blindsnake radiation. J Biogeogr, 40: 928-937

Martin H A. 2006. Cenozoic climatic change and the development of the arid vegetation in Australia. J Arid Environ, 66: 533-563

McIlveen R. 2010. Fundamentals of Weather and Climate. 2nd edition. New York: Oxford University Press. 527-534

Miller HB, Vasconcelos P M, Eiler J M, Farley K A. 2017. A Cenozoic terrestrial paleoclimate record from He dating and stable isotope geochemistry of goethites from Western Australia. Geology, 45: 895-898

Molnar P, Stock J K. 2009. Slowing of India's convergence with Eurasia since $20 \mathrm{Ma}$ and its implications for Tibetan mantle dynamics. Tectonics, 28: TC3001

Nicholson S E. 2009. A revised picture of the structure of the "monsoon" and land ITCZ over West Africa. Clim Dyn, 32: 1155-1171

Polissar P J, Freeman K H, Rowley D B, McInerney F A, Currie B S. 2009. Paleoaltimetry of the Tibetan Plateau from D/H ratios of lipid biomarkers. Earth Planet Sci Lett, 287: 64-76

Popov S V, Shcherba I G, Ilyina L B, Nevesskaya L A, Paramonova N P, Khondkarian S O, Magyar, I. 2006. Late Miocene to Pliocene palaeogeography of the Paratethys and its relation to the Mediterranean. Palaeogeogr Palaeoclim Palaeoecol, 238: 91-106

Quade J, Cerling T E, Bowman J R. 1989. Development of Asian monsoon revealed by marked ecological shift during the latest Miocene in northern Pakistan. Nature, 342: 163-166

Quan C, Liu Y S, Utescher T. 2012. Eocene monsoon prevalence over China: A paleobotanical perspective. Palaeogeogr Palaeoclim Palaeoecol, 365: 302-311

Ramstein G, Fluteau F, Besse J, Joussaume S. 1997. Effect of orogeny, plate motion and land-sea distribution on Eurasian climate change over the past 30 million years. Nature, 386: 788-795

Rea D K, Snoeckx H, Joseph L H. 1998. Late Cenozoic Eolian deposition in the North Pacific: Asian drying, Tibetan uplift, and cooling of the northern hemisphere. Paleoceanography, 13: $215-224$

Rix M G, Cooper S J B, Meusemann K, Klopfstein S, Harrison S E, Harvey M S, Austin A D. 2017. Post-Eocene climate change across continental Australia and the diversification of Australasian spiny trapdoor spiders (Idiopidae: Arbanitinae). Mol Phylogenet Evol, 109: 302-320 
Rodwell M J, Hoskins B J. 1996. Monsoons and the dynamic of deserts. Q J Roy Meteor Soc, 122: $1385-1404$

Rowley D B, Currie B S. 2006: Palaeo-altimetry of the late Eocene to Miocene Lunpola basin, central Tibet. Nature, 439: 677-681

Scotese C R. 2004. A continental drift flipbook. J Geol, 112: 729-741

Searle M P, Windley B F, Coward M P, Cooper D J W, Rex A J, Rex D, Tingdong L I, Xiao X, Jan M Q, Thakur V C. 1987. The closing of Tethys and the tectonics of the Himalaya. Geol Soc Am Bull, 98: 678-701

Senut B, Pickford M, Ségalen L. 2009. Neogene desertification of Africa. C R Geosci, 341: 591602

Shi Z G, Liu X D, An Z S, Yi B, Yang P, Mahowald N. 2011. Simulated variations of eolian dust from inner Asian deserts at the mid-Pliocene, last glacial maximum, and present day: contributions from the regional tectonic uplift and global climate change. Clim Dyn, 37: 22892301

Shukla A, Mehrotra R C, Spicer R A, Spicer T E V, Kumar M. 2014. Cool equatorial terrestrial temperatures and the South Asian monsoon in the Early Eocene: Evidence from the Gurha Mine, Rajasthan, India. Palaeogeogr Palaeoclim Palaeoecol, 412: 187-198

Smith R S, Gregory J M, Osprey A. 2008. A description of the FAMOUS (version XDBUA) climate model and control run. Geosci Model Dev, 1: 53-68

Smith R S, Gregory J. 2012. The last glacial cycle: transient simulations with an AOGCM. Clim Dyn, 38: 1545-1559

Spicer R, Yang J, Herman A, Kodrul T, Aleksandrova G, Maslova N, Spicer T, Ding L, Xu Q, Shukla A, Srivastava G, Mehrotra R, Liu X Y, Jin J H. 2017. Paleogene monsoons across India and South China: Drivers of biotic change. Gondwana Res, 49: 350-363

Sun J M, Windley B F. 2015. Onset of aridification by 34 Ma across the Eocene-Oligocene transition in Central Asia. Geology, 43: 1015-1018

Sun J, Gong Z, Tian Z, Jia Y, Windley B. 2015. Late Miocene stepwise aridification in the Asian interior and the interplay between tectonics and climate. Palaeogeogr Palaeoclim Palaeoecol, 421: 48-59

Sun X J, Wang P X. 2005. How old is the Asian monsoon system?-Palaeobotanical records from China. Palaeogeogr Palaeoclim Palaeoecol, 222: 181-222

Sun Y B, An Z S. 2002. History and variability of Asian interior aridity recorded by eolian flux in the Chinese Loess Plateau during the past $7 \mathrm{Ma}$. Sci China Earth Sci, 45: 420-429

Veranso-Libalah M C, Kadereit G, Stone R D, Couvreur T L. 2018. Multiple shifts to open habitats in Melastomateae (Melastomataceae) congruent with the increase of African Neogene climatic aridity. J Biogeogr, 45: 1420-1431.

Wang B, Ding Q. 2006. Changes in global monsoon precipitation over the past 56 years. Geophys Res Lett, 33: 272-288

Wang C S, Dai J G, Zhao X X, Li Y L, Graham S A, He D F, Ran B, Meng J. 2014. Outward-growth of the Tibetan Plateau during the Cenozoic: A review. Tectonophysics, 621: 1-43

Wang P X. 2009. Global monsoon in a geological perspective. Chin Sci Bull, 54: 1113-1136

Webster P J. 1987. The elementary monsoon. In Fein J S, Stephens P L, eds. Monsoons, New York: John Wiley. 3-32 
Webster P J. 2004. The elementary Hadley circulation. In Diaz H F, Bradley R S, eds. Present, Past and Future. Dordrecht: Springer. 9-60

Wei H H, Meng Q R, Ding L, Li Z Y. 2013. Tertiary evolution of the western Tarim basin, northwest China: A tectono-sedimentary response to northward indentation of the Pamir salient. Tectonics, 32: 558-575

Williams M. 2015. Interactions between fluvial and eolian geomorphic systems and processes: Examples from the Sahara and Australia. Catena, 134: 4-13

Wu G X, Liu Y M, Bian H, Bao Q, Duan AM, Jin F F. 2012. Thermal controls on the Asian summer monsoon. Sci Rep, 2: 404

Wu G X, Liu Y, Zhu X, Li W, Ren R, Duan A, Liang X. 2009. Multi-scale forcing and the formation of subtropical desert and monsoon. Ann Geophys, 27: 3631-3644

Wyrwoll K H, Miller G H. 2001. Initiation of the Australian summer monsoon 14,000 years ago. Quat Int, 83-85: 119-128

Xie P, Arkin P A. 1996. Analyses of global monthly precipitation using gauge observations, satellite estimates, and numerical model predictions. J Clim, 9: 840-858

Zachos J, Pagani M, Sloan L, Thomas E, Billups K. 2001. Trends, rhythms, and aberrations in global climate 65 Ma to present. Science, 292, 686-693

Žagar N, Skok G, Tribbia J. 2011. Climatology of the ITCZ derived from ERA Interim reanalyses. J Geophys Res Atmos, 116: D15103, D15103, doi:10.1029/2011JD015695

Zhang Z S, Flatøy F, Wang H J, Bethke I, Bentsen M, Guo Z T. 2012. Early Eocene Asian climate dominated by desert and steppe with limited monsoons. J Asian Earth Sci, 44: 24-35

Zhang Z S, Ramstein G, Schuster M, Li C, Contoux C, Yan Q. 2014. Aridification of the Sahara desert caused by Tethys Sea shrinkage during the Late Miocene. Nature, 513: 401-404

Zhao S Q. 1983. A new scheme for comprehensive geographical regionalization in China. Acta Geographica Sinica, 38: 1-10

Zhuang G, Pagani M, Zhang Y G. 2017. Monsoonal upwelling in the western Arabian Sea since the middle Miocene. Geology, 45: 655-658

Figure captions

Figure 1 Distributions of present day Asian-African-Australian monsoon regions (green shadows) and arid regions (yellow shadows). (a) Simulation; (b) Observation. The blue shaded area is ocean or lake, and the red outline indicates the $1500 \mathrm{~m}$ topographic contour of the Tibetan Plateau.

Figure 2 Distributions of Asian-African-Australian monsoon regions (green shadows) and arid regions (yellow shadows) in five periods of the Cenozoic. (a) mid-Paleocene (60Ma); (b) lateEocene (40Ma); (c) late-Oligocene (25Ma); (d) late-Miocene (10Ma); (e) present-day (0Ma). The blue shadows are oceans or lakes, and the black outline indicates the $1500 \mathrm{~m}$ topographic contour of the Tibetan Plateau.

Figure 3 Area changes of four monsoon regions (left column) and five arid regions (right column) in five periods of the Cenozoic. (a) North Africa monsoon region; (b) South Africa monsoon region; (c) Asian monsoon region; (d) Australian monsoon region; (e) North Africa arid region; (f) South 
Africa arid region; (g) West Asia arid region (Asia west of $70^{\circ} \mathrm{E}$ ); (h) East Asia arid region (Asia east of $70^{\circ} \mathrm{E}$ ), (i) Australian arid region. Area unit: $10^{4} \mathrm{~km}^{2}$

Figure 4 Distributions of the Northern Hemisphere winter mean (left column) and summer mean (right column) precipitation (shadows) and $500 \mathrm{hPa}$ vertical velocity (contours) in five periods of the Cenozoic. (a), (f) mid-Paleocene; (b), (g) late-Eocene; (c), (h) late-Oligocene; (d), (i) lateMiocene; (e), (j) present-day. Precipitation rate unit: $\mathrm{mm} \mathrm{d}^{-1}$, vertical velocity interval: $0.01 \mathrm{~Pa} \mathrm{~s}^{-1}$. The red lines are zero contours. The negative values indicate ascending motion.

Figure 5 Comparison of the Asia-Africa-Australia monsoon regions (green shadows) and the coverages of the ITCZ (areas where $\omega<-0.015 \mathrm{~Pa} \mathrm{~s}^{-1}$ at $500 \mathrm{hPa}$ ) in boreal winter (blue lines) and boreal summer (red lines) for five periods of the Cenozoic. (a) mid-Paleocene; (b) late-Eocene; (c) late-Oligocene; (d) late-Miocene; (e) present-day. Grey contours indicate the $1500 \mathrm{~m}$ topographic contour of the Tibetan Plateau.

Figure 6 850hPa summer mean streamline fields with the northern boundary (red lines) of summer monsoon over East Asia (left column) and variations of summer precipitation rate $\left(\mathrm{mm} \mathrm{d}^{-1}\right)$ averaged for the longitude band $\left(105-120^{\circ} \mathrm{E}\right)$ of East Asian monsoon with latitude (right column) in five periods of the Cenozoic. (a), (f) mid-Paleocene; (b), (g) late-Eocene; (c), (h) late-Oligocene; (d), (i) late-Miocene; (e), (j) present-day. The blue and black shadows indicate the topography of the ocean and the plateau, respectively in (a)-(e).

Figure 7 Distribution of the Asia-Africa-Australia arid regions (yellow shadows) and annual mean sea level pressure fields (contours) in five periods of the Cenozoic. (a), (f) mid-Paleocene; (b), (g) late-Eocene; (c), (h) late-Oligocene; (d), (i) late-Miocene; (e), (j) present-day. The red isobars indicate the high pressure zone. Unit of sea level pressure: $\mathrm{hPa}$.

Figure 8 Latitude-pressure cross sections of global zonal mean (left column) and Asian (70-120 $\mathrm{E}$ ) sectorially mean (right column) meridional mass stream function (shadows) and meridional circulation (wind vectors) in five periods of the Cenozoic. From top to bottom, results of midPaleocene, late-Eocene, late-Oligocene, late-Miocene and present-day are shown, respectively. Unit of stream function: $10^{10} \mathrm{~kg} \mathrm{~s}^{-1}$, Unit of meridional wind speed: $\mathrm{m} \mathrm{s}^{-1}$, Unit of vertical wind speed: $10^{-2} \mathrm{~Pa} \mathrm{~s}^{-1}$.

Figure 9 Latitude-pressure cross sections of vertical velocity averaged for the longitude band (70$120^{\circ} \mathrm{E}$ ) where the Asia landmass is located. From top to bottom, results of mid-Paleocene, lateEocene, late-Oligocene, late-Miocene and present-day are shown, respectively. Yellow shadows indicate ascending motion areas. Unit: $10^{-2} \mathrm{~Pa} \mathrm{~s}^{-1}$.

Figure 10 Comparative experiments simulated distributions of monsoon regions (green shades) and arid regions (yellow shades) in the four land-ocean configurations without topography and in the late-Eocene land-ocean configuration and pre-industrial $\mathrm{CO}_{2}$ level condition with and without topography. (a), (b), (c) and (d) correspond to the late-Eocene, late-Oligocene, late-Miocene and present-day land-sea patterns but no topographic experiments, respectively; (e), (f) correspond to topography and no topography experiments, respectively, under condition of the late-Eocene land- 
sea pattern and pre-industrial $\mathrm{CO}_{2}$ level. Blue shadows show oceans or lakes. The gray outline indicates $1500 \mathrm{~m}$ topographic contour in (e).

Figure 11 Regional topographic and land-sea distribution characteristics during the Cenozoic and changes in monsoon regions and arid regions in size. (a) the average altitude, area, latitude of the Tibetan Plateau above $1500 \mathrm{~m}$ and the area of Asian monsoon region; (b) the central latitude of the Tibetan Plateau, the area of the plateau above $1500 \mathrm{~m}$ north of $30^{\circ} \mathrm{N}$, and the area of the Asian inland arid region north of $40^{\circ} \mathrm{N}$ on the northern side of the plateau; (c) the areas of land, ocean and arid region in the mid-low latitudes from Western Europe-North Africa to Central Asia $\left(20^{\circ} \mathrm{W}-100^{\circ} \mathrm{E}\right.$, $20^{\circ} \mathrm{N}-60^{\circ} \mathrm{N}$ ); (d) the northernmost latitude of Australian continent, area of Australian monsoon region, central latitude of Australian continent and area of Australian arid region. Area unit: $10^{4}$ 
$\mathrm{km}^{2}$.

742

743

744

745

746

747

748
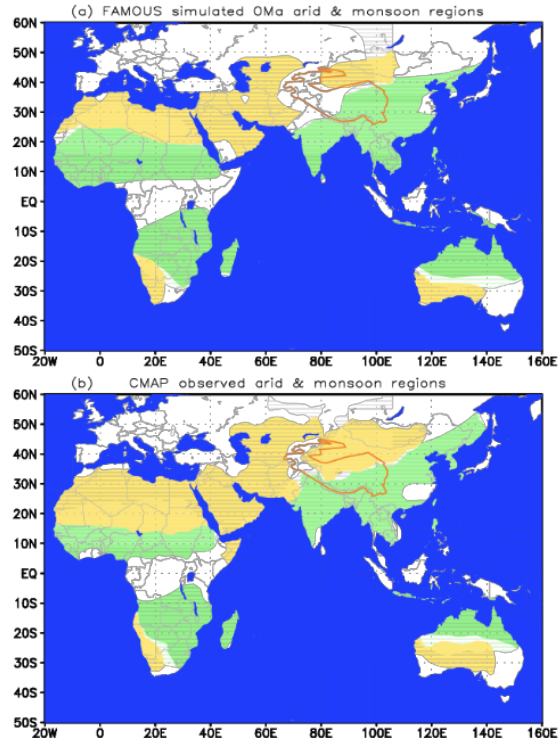

图 1 模式模拟的 (a) 和观测的 (b) 现代亚-非-澳洲季风区 (绿色阴影) 和干旱区 (黄色 阴影）分布。蓝色阴影区为海洋或湖泊，红色廓线指示青藏高原 $1500 \mathrm{~m}$ 地形等高线 

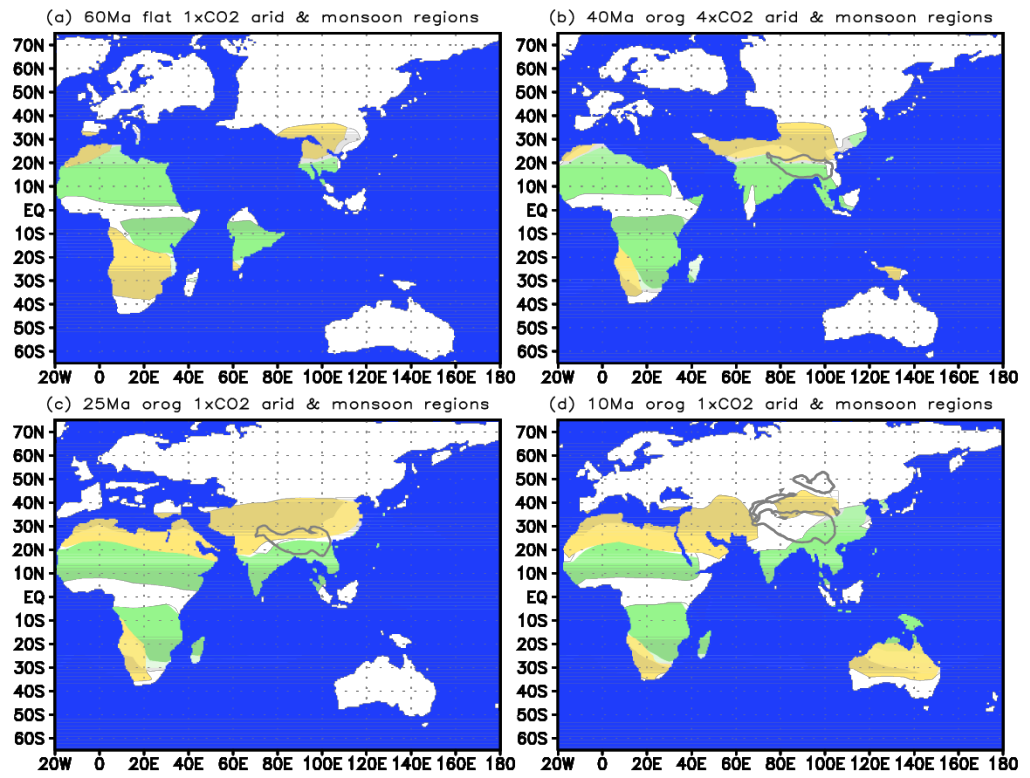

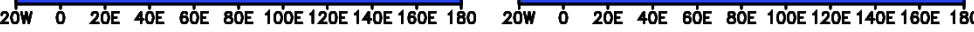

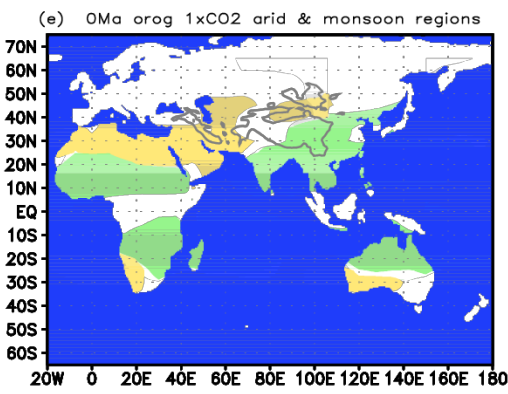

图 2 新生代 5 个时期亚-非-澳洲季风区 (绿色阴影) 和干旱区 (黄色阴影) 分布。（a）中 古新世(60Ma)，（b）晚始新世(40Ma)，（c）晚渐新世(25Ma)，(d) 晚中新世(10Ma)和（e） 现代(OMa)。蓝色阴影区为海洋或湖泊, 黑色影线指示青藏高原 $1500 \mathrm{~m}$ 地形等高线 


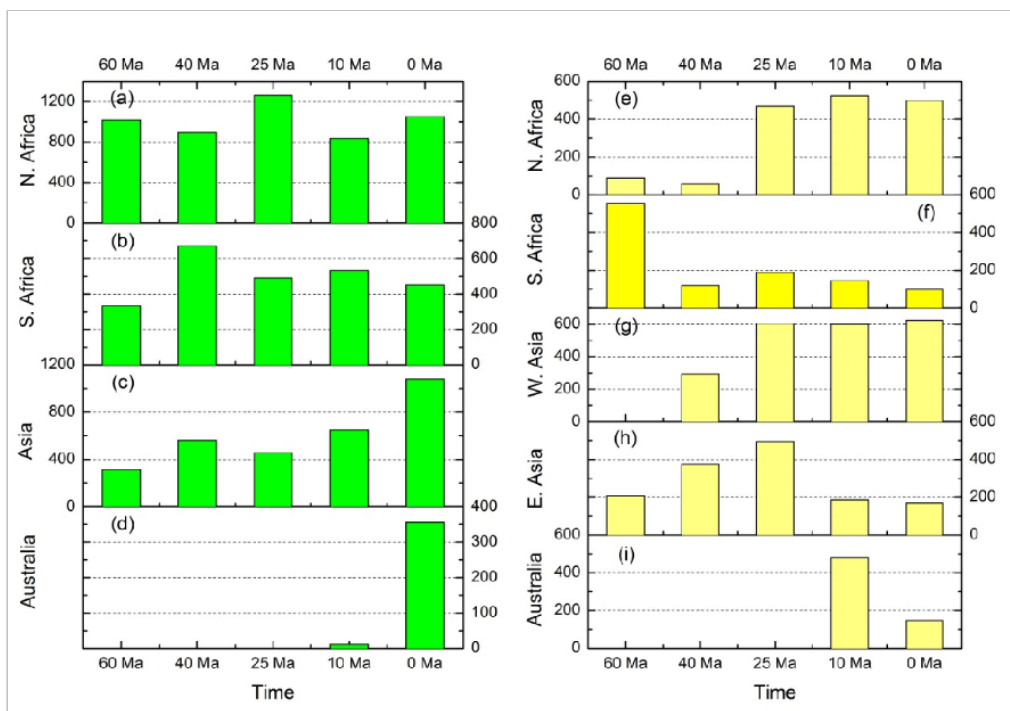

图 3 新生代 5 个时期 4 个季风区面积变化 (左列)，（a）北非季风区，(b) 南非季风区,

（c）亚洲季风区，（d）澳洲季风区; 以及 5 个干旱区面积变化（右列）, (e) 北非干旱 区, (f) 南非干旱区, (g) 西亚干旱区 (亚洲 $70^{\circ} \mathrm{E}$ 以西), （h）东亚干旱区 (亚洲 $70^{\circ} \mathrm{E}$ 以东），(i) 澳洲干早区。面积单位为 $10^{4} \mathrm{~km}^{2}$ 。 

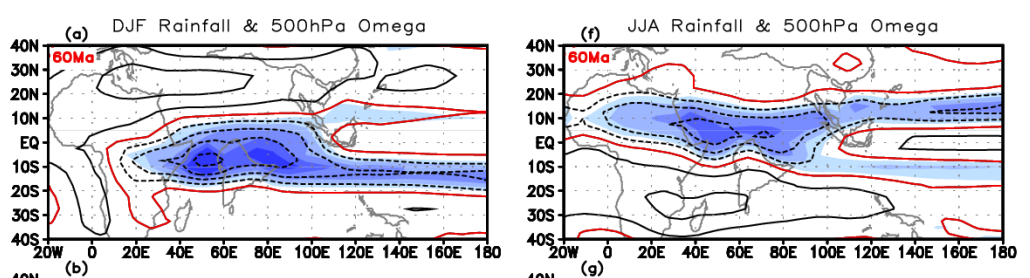

40N $\frac{\text { (b) }}{40 \mathrm{Ma}}$

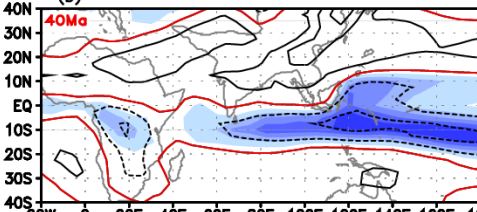

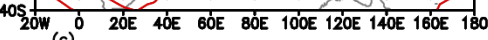

$$
{ }^{40 \mathrm{~N}} 2 \mathrm{~W}
$$

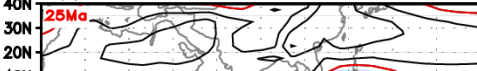

10N-

EQ $\quad \therefore$

${ }_{205}^{105} \bigcirc 160$

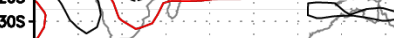

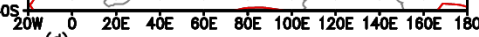

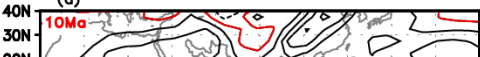

$30 \mathrm{~N}$

${ }_{10 N}^{20 N}$

EQ

205-)

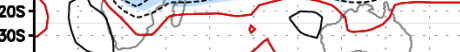

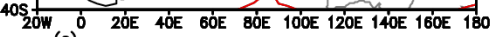

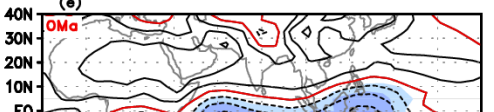

COC

(C)

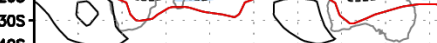

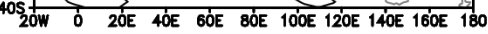

图 $460 \mathrm{Ma} 、 40 \mathrm{Ma} 、 25 \mathrm{Ma} 、 10 \mathrm{Ma}$ 和 $0 \mathrm{Ma}$ 北半球冬季 (DJF) 平均 (左列) 和夏季 (JJA) 平均 (右列) 降水率 (阴影, $\mathrm{mm} / \mathrm{d}$ ) 和 $500 \mathrm{hPa}$ 垂直速度 (等值线, 间隔为 $0.01 \mathrm{~Pa} / \mathrm{s}$, 红线 为零线, 负值指示上升运动) 分布 

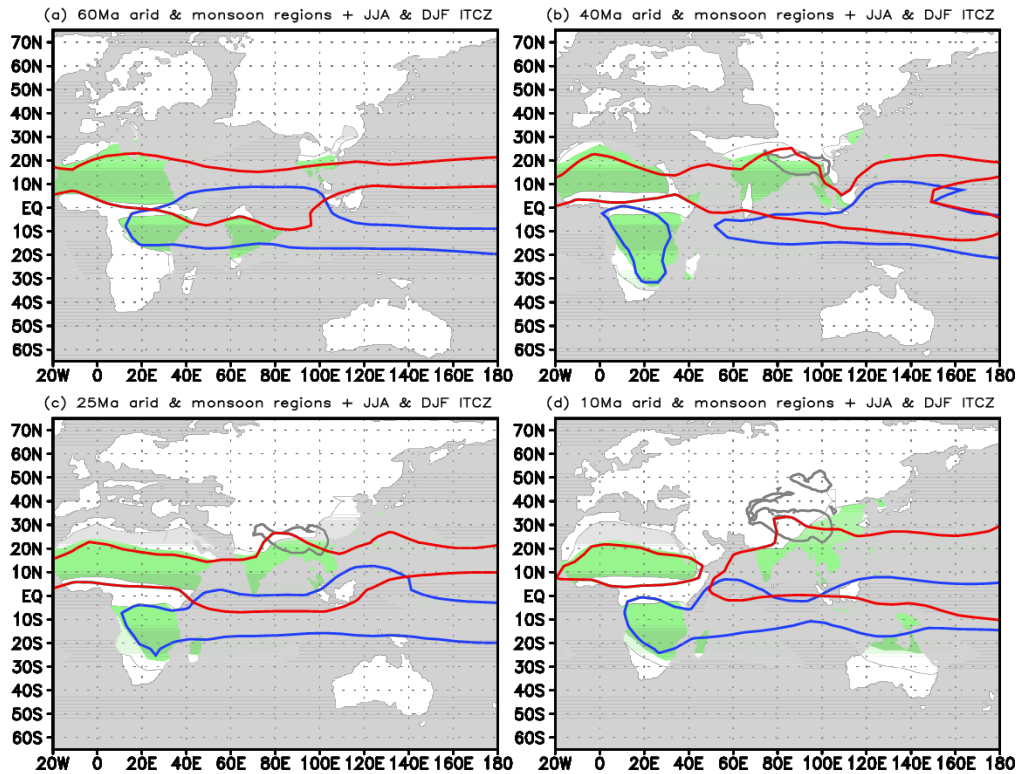

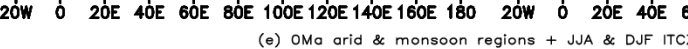

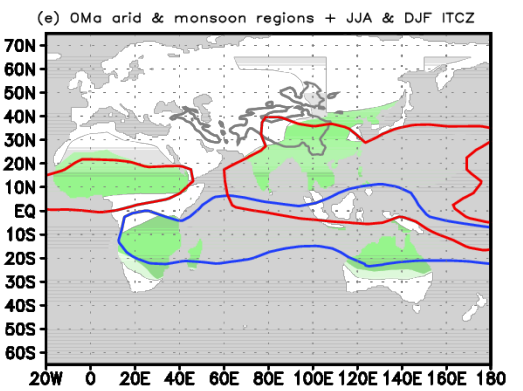

图 5 新生代 5 个时期亚-非-澳洲季风区 (绿色阴影) 与冬季 (DJF, 蓝线) 平均和夏季 (JJA, 红线)平均 ITCZ 覆盖范围 ( $500 \mathrm{hPa}$ 上 $\omega<-0.015 \mathrm{~Pa} / \mathrm{s}$ 的区域) 分布。(a) 中古新世(60Ma), （b）晚始新世(40Ma), (c) 晚渐新世(25Ma), (d) 晚中新世(10Ma)和（e）现代(0Ma)。 灰色廓线指示青藏高原 $1500 \mathrm{~m}$ 地形等高线 
778
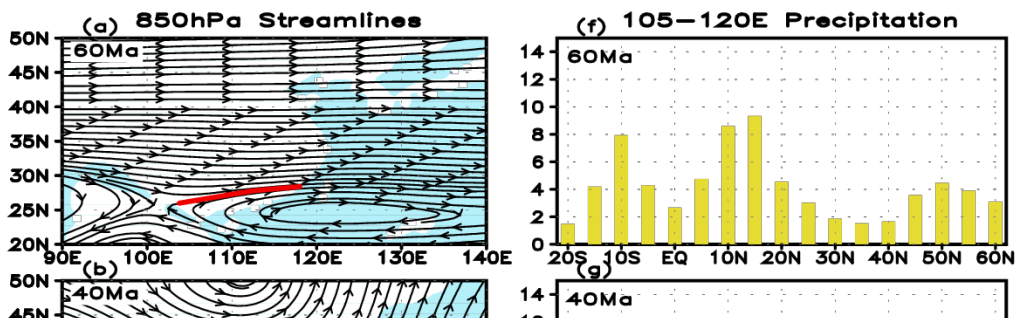

$45 \mathrm{~N}$

$40 \mathrm{~N}$

35N

$30 \mathrm{~N}$
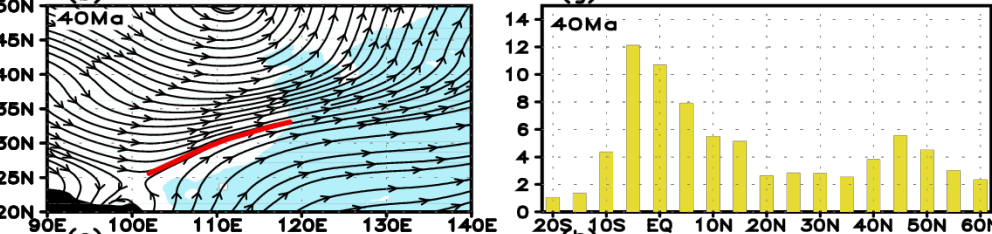

$20{ }^{\circ O E}$ (c) $100 \mathrm{E}$ 110E $120 \mathrm{E}$ 130E $140 \mathrm{E}$

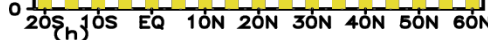

$45 \mathrm{~N}$

$40 \mathrm{~N}$

35N

3ON

$25 \mathrm{~N}$

20N
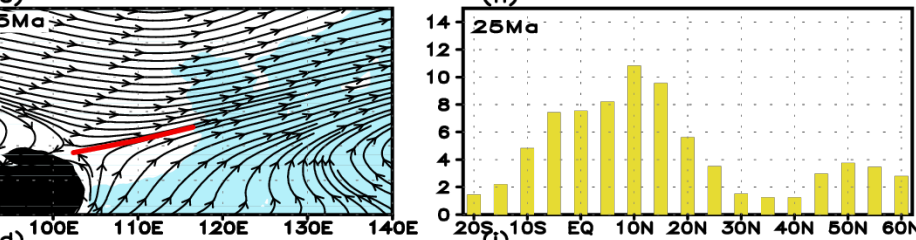

$50 \mathrm{~N} \frac{(d)}{10 \mathrm{Ma}}$

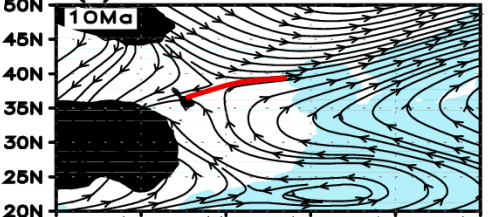

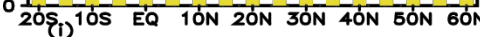

$1 4 \longdiv { 1 0 M 0 }$

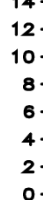

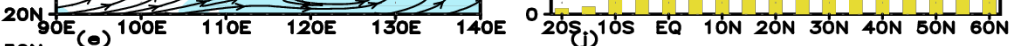

5ON

$45 \mathrm{~N}$

$40 \mathrm{~N}$

$35 \mathrm{~N}$

$30 \mathrm{~N}$

$25 \mathrm{~N}$
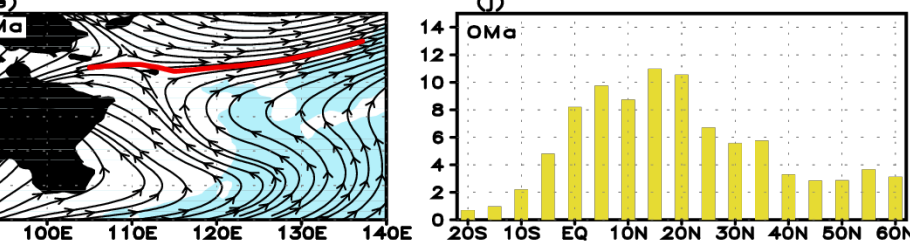

图 $660 \mathrm{Ma}(\mathrm{a}) 、 40 \mathrm{Ma}(\mathrm{b}) 、 25 \mathrm{Ma}(\mathrm{c}) 、 10 \mathrm{Ma}(\mathrm{d})$ 和 $0 \mathrm{Ma}(\mathrm{e})$ 东亚夏季风北界位置（红色粗线）, 蓝色和黑色阴影区分别指示海洋和青藏高原地形。60Ma (f)、40Ma (g)、25Ma (h)、10Ma (i) 和 $0 \mathrm{Ma}(\mathrm{j})$ 东亚所在经度带内纬向平均降水率 $(\mathrm{mm} / \mathrm{d})$ 随纬度的变化 


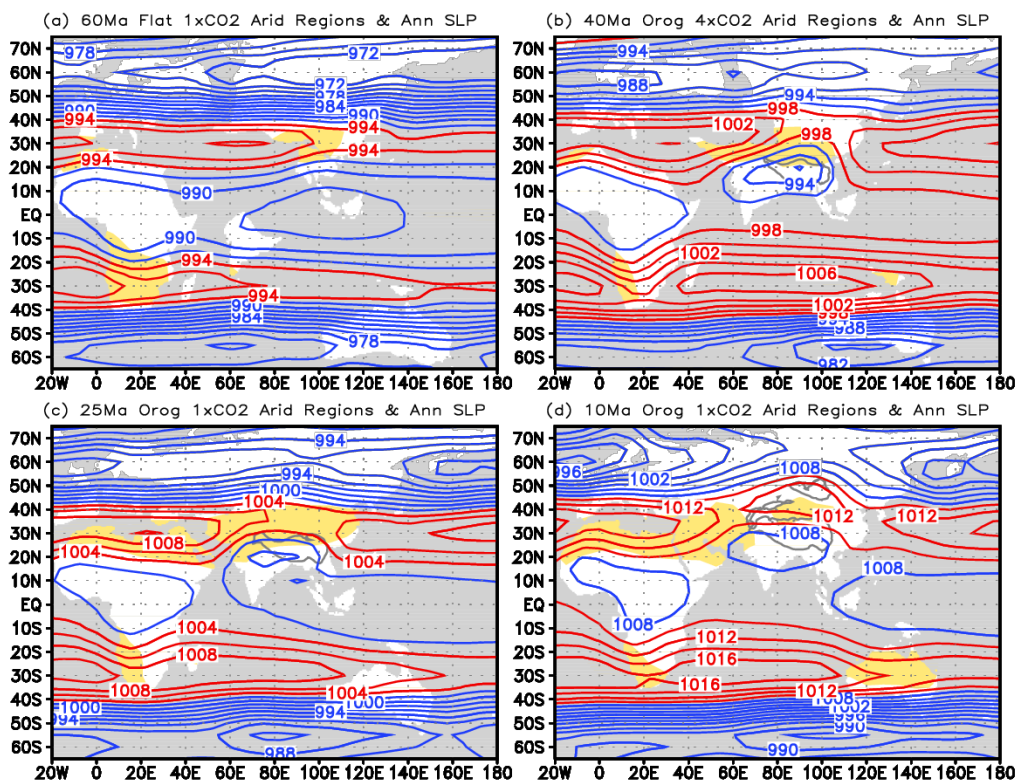

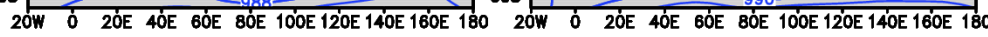

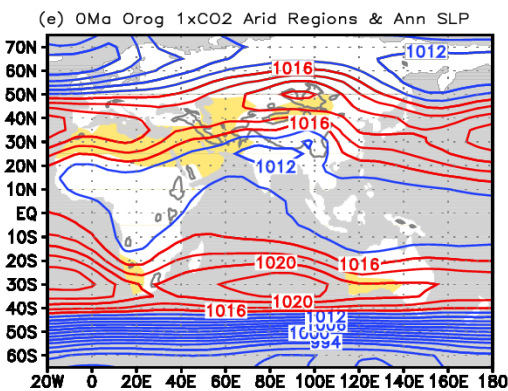

图 7 新生代 5 个时期亚-非-澳洲干旱区 (黄色阴影) 与年平均海平面气压场 (等值线, 红色 等压线指示了高压带) 分布。（a）中古新世(60Ma), (b) 晚始新世(40Ma), (c) 晚渐新 世(25Ma)，（d）晚中新世(10Ma)和（e）现代(0Ma) 

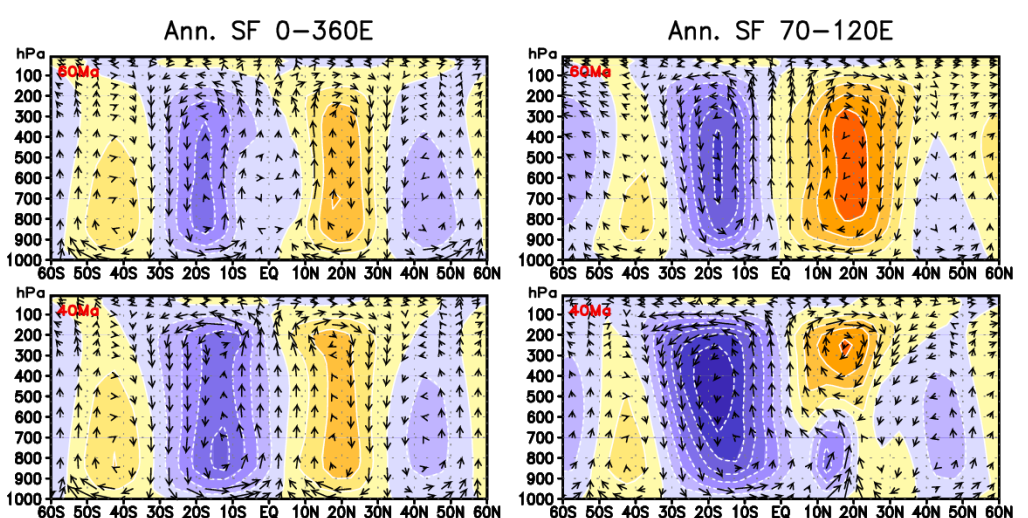

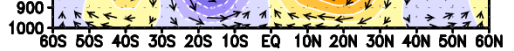
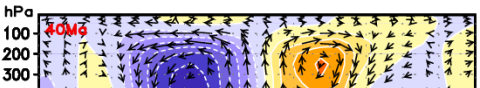

$400-$.

$400-1-1+2+24$

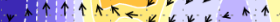

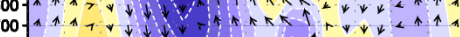

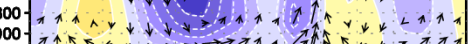

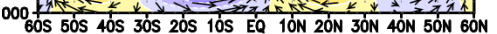

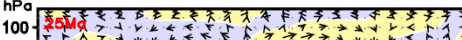

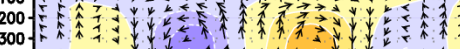

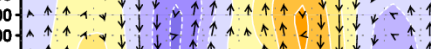

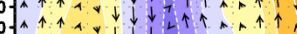

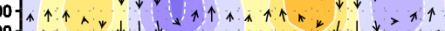

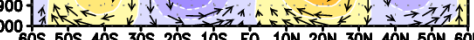

6OS 6OS 4OS 3OS 205 1OS EQ 1ON 2ON 3ÓN 4ON 5ON 6ON

6OS 6ÓS 4OS 3OS 2OS 1OS EQ ION 2ON 3ON 4ON 5ÓN 6ON
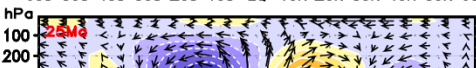

300

作

$600-7$

300 .

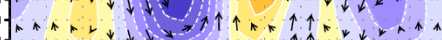

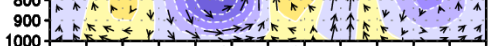

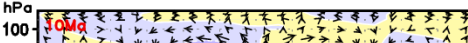

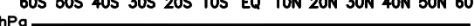

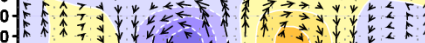

(000-

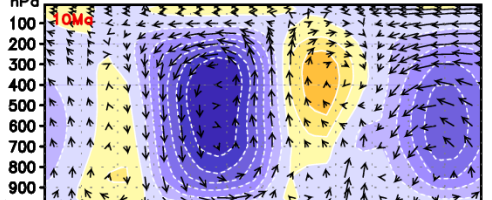

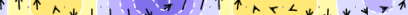

OOS 6OS 40S 30S 20S 10S EQ 1ON 2ON 30N 40N 5ON BON

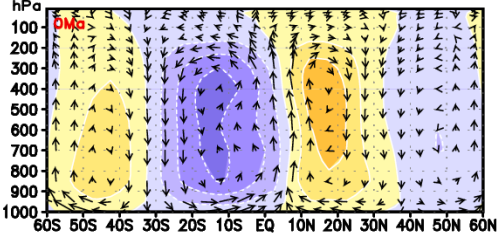

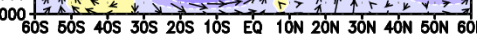

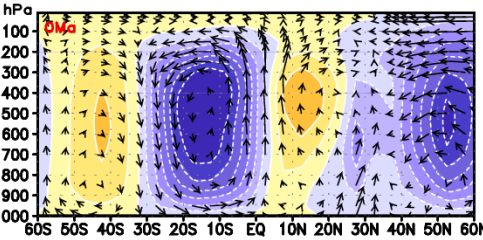

$\overrightarrow{4}$

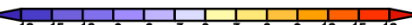

图 $860 \mathrm{Ma} 、 40 \mathrm{Ma} 、 25 \mathrm{Ma} 、 10 \mathrm{Ma}$ 和 $0 \mathrm{Ma}$ 全球纬向平均 (左列) 及亚洲所在经度带 $\left(70-120^{\circ} \mathrm{E}\right.$ ) 内纬向平均 (右列) 经向质量流函数 (阴影, $10^{10} \mathrm{~kg} / \mathrm{s}$ ) 和径向环流 (风矢, 经向风速单位 为 $\mathrm{m} / \mathrm{s}$, 垂直风速单位为 $-10^{-2} \mathrm{~Pa} / \mathrm{s}$ ) 剖面 

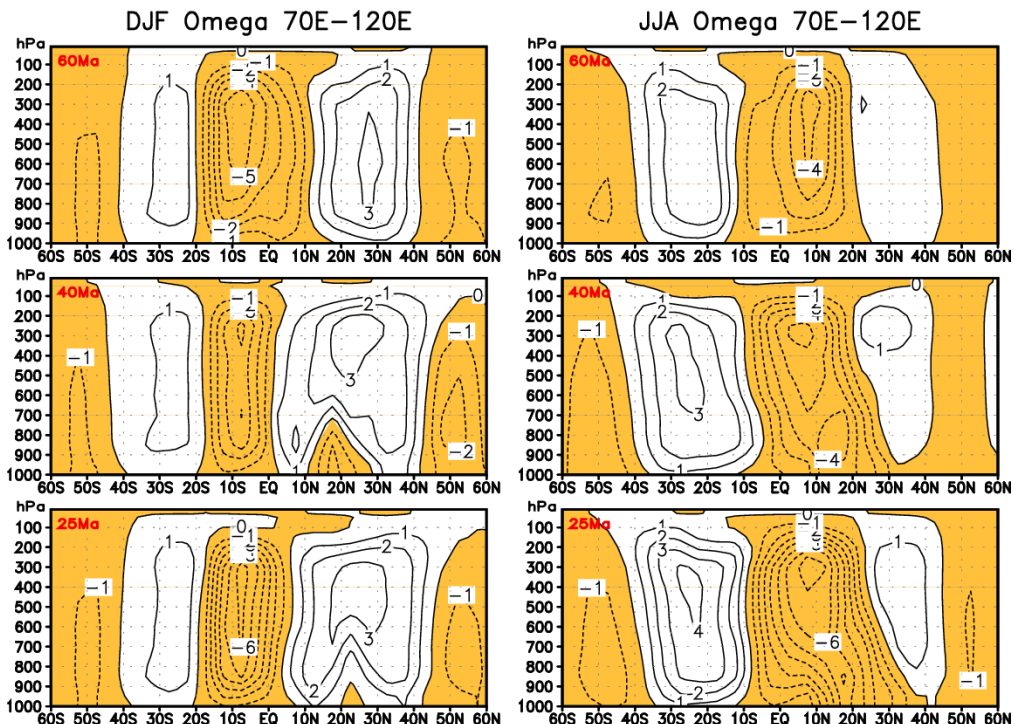

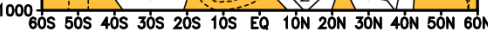
$\mathrm{hPo}$
100
200
300
400
500
600
700
800
900

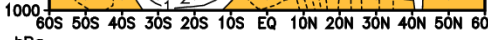
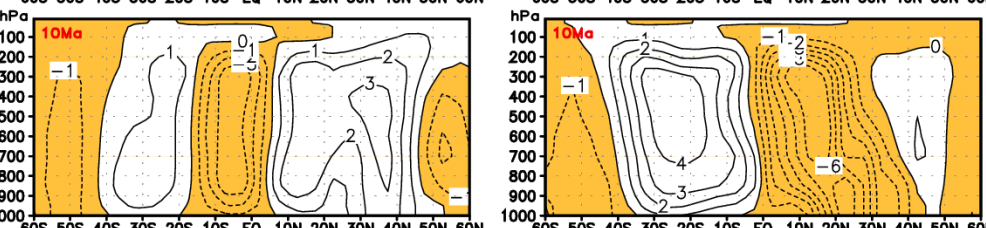

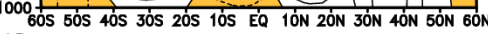
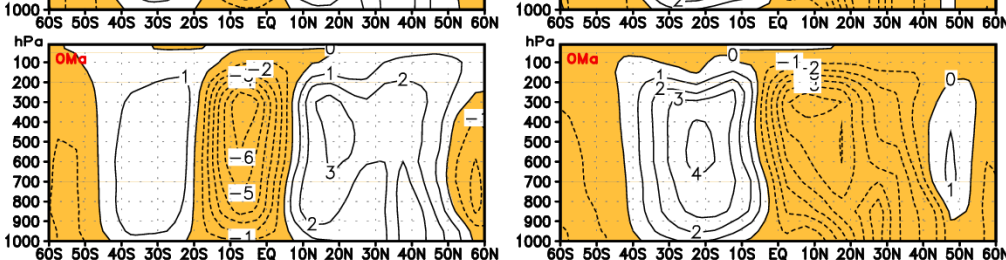

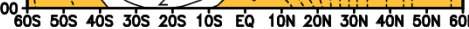

801

图 $960 \mathrm{Ma} 、 40 \mathrm{Ma} 、 25 \mathrm{Ma} 、 10 \mathrm{Ma}$ 和 $0 \mathrm{Ma}$ 亚洲区域 $\left(70-120^{\circ} \mathrm{E}\right)$ 冬季 (左列) 和夏季 (右列) 纬向平均垂直风速 $\left(10^{-2} \mathrm{~Pa} / \mathrm{s}\right.$, 阴影指示上升运动区 $)$ 剖面 


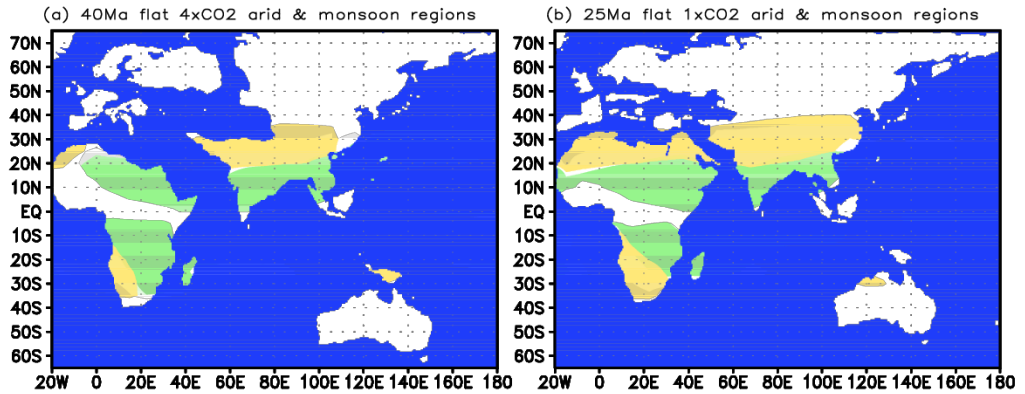
$\begin{array}{ll}\text { (c) } 10 \mathrm{Ma} \text { flat } 1 \times \mathrm{CO} 2 \text { arid \& monsoon regions } & \text { (d) OMa flat } 1 \times \mathrm{CO} 2 \text { arid \& monsoon regions }\end{array}$
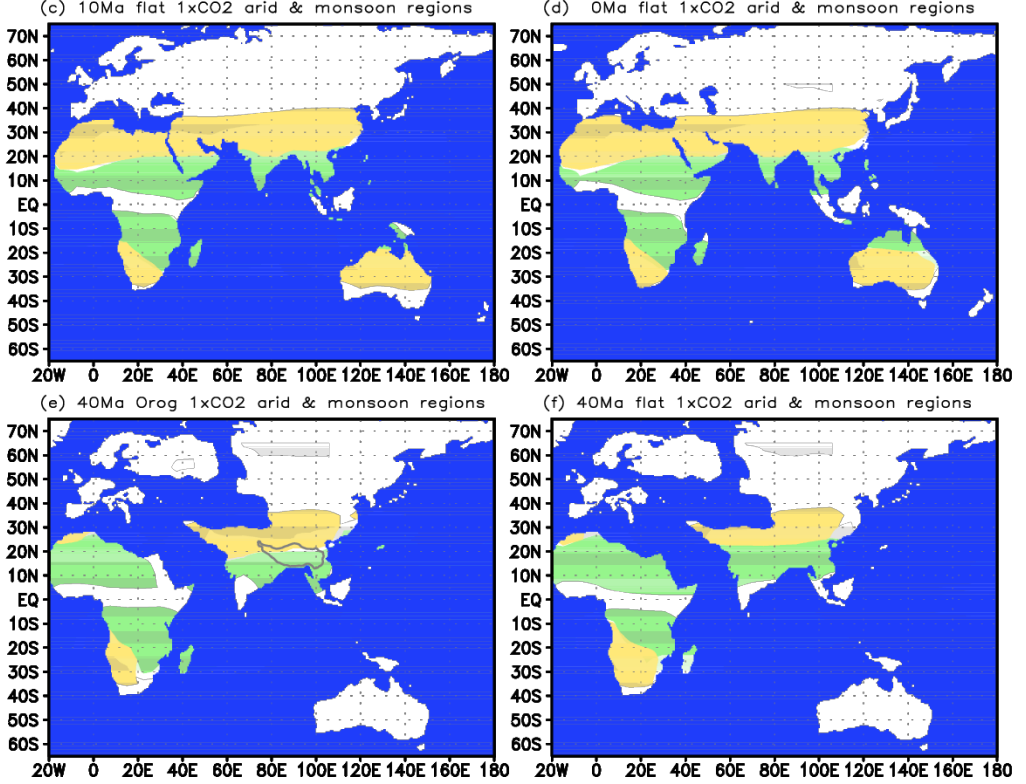

80

808 图 10 对应于晚始新世 $(\mathrm{a}, 40 \mathrm{Ma}) 、$ 晚渐新世(b, 25Ma)、晚中新世 $(\mathrm{c}, 10 \mathrm{Ma})$ 和现代(d, 0Ma)海 809 陆格局但无地形条件下模拟的季风区(绿色阴影)和干早区(黄色阴影)分布, 以及在晚始新世 810 (40Ma)海陆格局和 1 倍大气 $\mathrm{CO}_{2}$ 浓度条件下且有地形 $(\mathrm{e}$, 黑色廓线指示青藏高原 $1500 \mathrm{~m}$ 地 811 形等高线)和无地形(f)试验模拟的季风区(绿色阴影)和干旱区(黄色阴影)分布, 蓝色阴影区为 

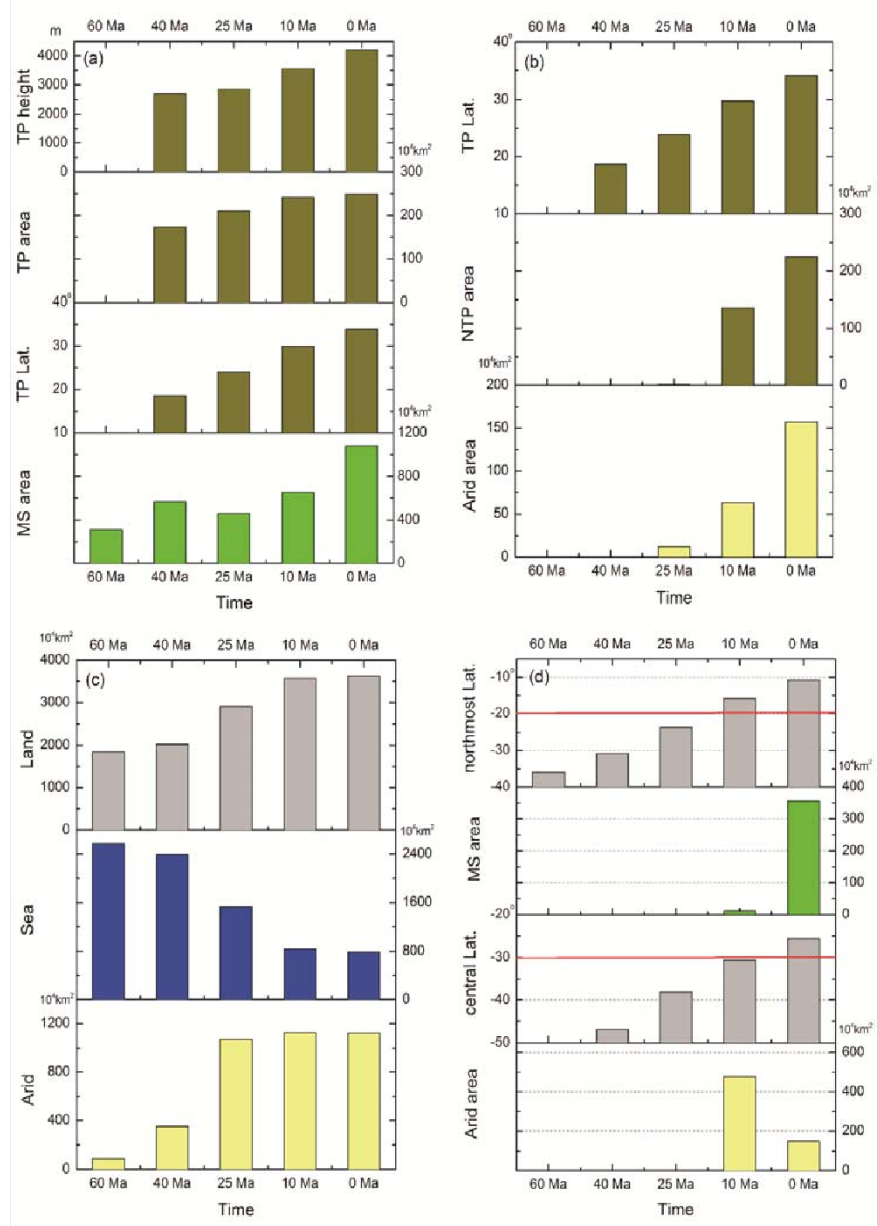

816

11 新生代区域地形和海陆分布特征与季风区和干早区面积变化。（a） $1500 \mathrm{~m}$ 以上青藏 高原平均高度、面积、纬度及亚洲季风区面积;（b）青藏高原中心纬度、 $1500 \mathrm{~m}$ 以上 $30^{\circ} \mathrm{N}$ 以北高原面积及高原北侧 $40^{\circ} \mathrm{N}$ 以北亚洲内陆干旱区面积; (c) 西欧-北非至中亚的中低纬 度地区 $\left(20^{\circ} \mathrm{W}-100^{\circ} \mathrm{E}, 20^{\circ} \mathrm{N}-60^{\circ} \mathrm{N}\right)$ 陆地、海洋及干旱区面积; (d) 澳大利亚大陆最北纬度、 澳洲季风区面积、澳大利亚大陆中心纬度及澳洲干旱区面积 